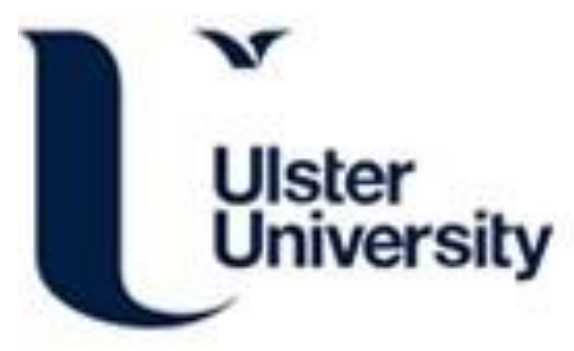

\title{
Tertiary treatment of urban wastewater by solar and UV-C driven advanced oxidation with peracetic acid: effect on contaminants of emerging concern and antibiotic resistance
}

Rizzo, L., Agovino, T., Nahim-Granados, S., Castro-Alférez, M., Fernandez-lbanez, P., \& Polo-López, M. I.

(2018). Tertiary treatment of urban wastewater by solar and UV-C driven advanced oxidation with peracetic acid: effect on contaminants of emerging concern and antibiotic resistance. Water Research, 149, 272.

https://doi.org/10.1016/j.watres.2018.11.031

Link to publication record in Ulster University Research Portal

Published in:

Water Research

Publication Status:

Published (in print/issue): 14/11/2018

DOI:

10.1016/j.watres.2018.11.031

Document Version

Author Accepted version

\section{General rights}

Copyright for the publications made accessible via Ulster University's Research Portal is retained by the author(s) and / or other copyright owners and it is a condition of accessing these publications that users recognise and abide by the legal requirements associated with these rights.

\section{Take down policy}

The Research Portal is Ulster University's institutional repository that provides access to Ulster's research outputs. Every effort has been made to ensure that content in the Research Portal does not infringe any person's rights, or applicable UK laws. If you discover content in the Research Portal that you believe breaches copyright or violates any law, please contact pure-support@ulster.ac.uk. 
Research

Elsevier Editorial System(tm) for Water

Manuscript Draft

Manuscript Number:

Title: Tertiary treatment of urban wastewater by solar and UV-C driven advanced oxidation with peracetic acid: effect on contaminants of emerging concern and antibiotic resistance

Article Type: Research Paper

Keywords: advanced oxidation processes; antibiotic resistant bacteria; peracetic acid; solar driven processes; wastewater treatment; water disinfection

Corresponding Author: Professor Luigi Rizzo, PhD

Corresponding Author's Institution: University of Salerno

First Author: Luigi Rizzo, PhD

Order of Authors: Luigi Rizzo, PhD; Teresa Agovino; Samira Nahim Granados; Maria Castro-Alférez; Pilar Fernández-Ibáñez; Maria I PoloLópez

Abstract: Photo driven advanced oxidation process (AOP) with peracetic acid (PAA) has been poorly investigated in water and wastewater treatment so far. In the present work its possible use as tertiary treatment of urban wastewater to effectively minimize the release into the environment of contaminants of emerging concern (CECs) and antibiotic resistant bacteria was investigated. Different initial PAA concentrations, two light sources (sunlight and UV-C) and two different water matrices (groundwater (GW) and wastewater (WW)) were studied. Low PAA doses were found to be effective in the inactivation of antibiotic resistant Escherichia coli (AR E. Coli) in GW, being UV-C driven process faster (detection limit (DL) achieved for a cumulative energy (QUV) of $0.3 \mathrm{kJL}-1$ with $0.2 \mathrm{mg}$ PAA L-1) than solar driven one (DL achieved at QUV=4.4 kJL-1 with $0.2 \mathrm{mg}$ PAA L-1). Really fast inactivation rates of indigenous AR E. coli were observed in WW. Higher QUV and PAA initial doses were necessary to effectively remove the three target CECs (carbamazepine (CBZ), diclofenac and sulfamethoxazole), being CBZ the more refractory one. In conclusion, photo driven AOP with PAA can be effectively used as tertiary treatment of urban wastewater but initial PAA dose should be optimized to find the best compromise between target bacteria inactivation and CECs removal as well as to prevent scavenging effect of PAA on hydroxyl radicals because of high PAA concentration.

Suggested Reviewers: Monica Brienza

Montpellier University

monica.brienza@ird.fr

Manuel A Manzano Quiñones

University of Cadiz

manuel.manzanoduca.es

Popi Karaolia 
University of Cyprus

Pkarao01@ucy.ac.cy

Sureyya Meric

Namik Kemal University

smeric@nku.edu.tr 
Dear Editor,

we kindly ask you to consider for possible publication in "Water Research" journal our research paper entitled:

\section{Tertiary treatment of urban wastewater by solar and UV-C driven advanced oxidation with peracetic acid: effect on contaminants of emerging concern and antibiotic resistance}

Photo driven advanced oxidation process (AOP) with peracetic acid (PAA) has been poorly investigated in water and wastewater treatment so far. In the present work, its possible use as tertiary treatment of urban wastewater to effectively minimize the release into the environment of contaminants of emerging concern (CECs) and antibiotic resistant bacteria was investigated. In particular, the effect of two light sources (sunlight and UVC) on the simultaneous inactivation of antibiotic resistant E. coli and removal from real wastewater of three CECs (namely, carbamazepine, diclofenac and sulfamethoxazole) (spiked) at quite realistic concentrations was investigated. To our knowledge, this is the first work where sunlight/PAA process has been investigated. In our opinion the results achieved can significantly advance the knowledge about photo driven AOP with PAA and its contribution to successfully address emerging challenges in urban wastewater treatment.

Our manuscript perfectly fits the scopes of your prestigious journal, and we trust you will find of interest for you and journal readers our work.

This work has not been published previously - also not in any other language-, it is not under consideration for publication elsewhere, and if accepted it will not be published elsewhere in the same form, or in any other language, without the written consent of the publisher.

Best regards

The corresponding authors

Luigi Rizzo

María Inmaculada Polo-López 


\section{Highlights}

- First time sunlight/PAA investigated in the removal of CECs

- Low PAA doses effective in the inactivation of AR E. coli by UV-C/PAA and sunlight/PAA

- Higher Quv and PAA initial doses are necessary to effectively remove the target CECs

- UV-C/PAA faster than sunlight/PAA in AR E. coli inactivation and CECs removal

- Sunlight/PAA possible option for tertiary treatment in small wastewater treatment plants 
Graphical Abstract

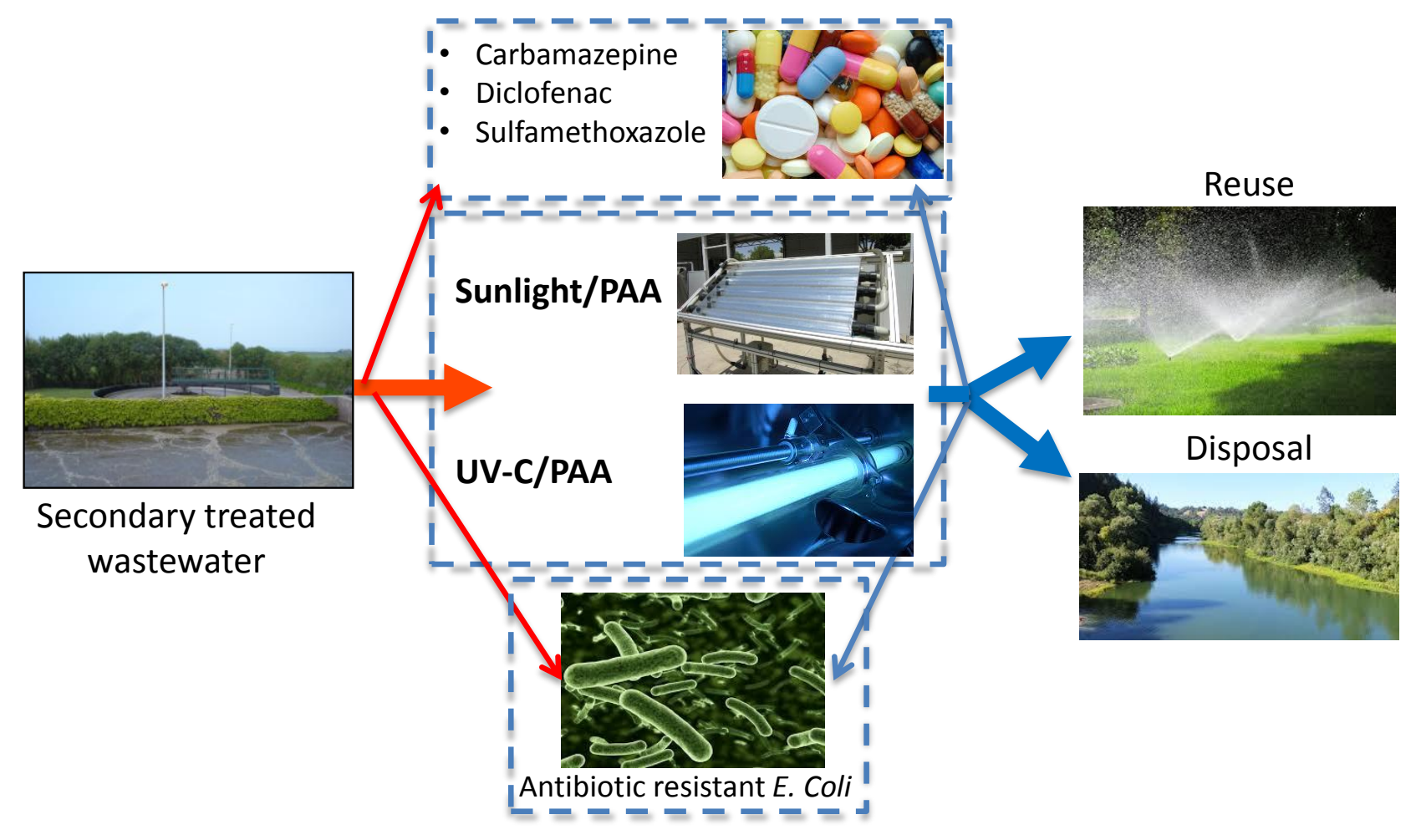



oxidation with peracetic acid: effect on contaminants of emerging concern and antibiotic resistance

5 Luigi Rizzo ${ }^{1, *}$, Teresa Agovino ${ }^{1}$, Samira Nahim-Granados ${ }^{2}$, María Castro-Alférez ${ }^{2}$, Pilar 6 Fernández-Ibáñez ${ }^{3}$, María Inmaculada Polo-López ${ }^{2, *}$

7

$8{ }^{1}$ Department of Civil Engineering, University of Salerno, Via Giovanni Paolo II 132, 984084 Fisciano (SA), Italy

$10{ }^{2}$ CIEMAT-Plataforma Solar de Almeria, P.O. Box 22, Tabernas (Almería), Spain.

$11{ }^{3}$ Nanotechnology and Integrated BioEngineering Centre, School of Engineering,

12 University of Ulster, Newtownabbey, Northern Ireland, United Kingdom 


\section{Abstract}

Photo driven advanced oxidation process (AOP) with peracetic acid (PAA) has been poorly investigated in water and wastewater treatment so far. In the present work its possible use as tertiary treatment of urban wastewater to effectively minimize the release into the environment of contaminants of emerging concern (CECs) and antibiotic resistant bacteria was investigated. Different initial PAA concentrations, two light sources (sunlight and $\mathrm{UV}-\mathrm{C}$ ) and two different water matrices (groundwater (GW) and wastewater (WW)) were studied. Low PAA doses were found to be effective in the inactivation of antibiotic resistant Escherichia coli (AR E. coli) in GW, being UV-C driven process faster (detection limit (DL) achieved for a cumulative energy (Quv) of $0.3 \mathrm{kJL}^{-1}$ with $0.2 \mathrm{mg} \mathrm{PAA} \mathrm{L}^{-1}$ ) than solar driven one (DL achieved at $\mathrm{QUV}_{\mathrm{UV}}=4.4 \mathrm{kJL}^{-1}$ with $0.2 \mathrm{mg}$ PAA L ${ }^{-1}$ ). Really fast inactivation rates of indigenous AR E. coli were observed in WW. Higher Quv and PAA initial doses were necessary to effectively remove the three target CECs (carbamazepine (CBZ), diclofenac and sulfamethoxazole), being CBZ the more refractory one. In conclusion, photo driven AOP with PAA can be effectively used as tertiary treatment of urban wastewater but initial PAA dose should be optimized to find the best compromise between target bacteria inactivation and CECs removal as well as to prevent scavenging effect of PAA on hydroxyl radicals because of high PAA concentration.

Keywords: advanced oxidation processes, antibiotic resistant bacteria, peracetic acid, solar driven processes, wastewater treatment, water disinfection. 


\section{Introduction}

The concern for the release into the environment of micro-contaminants from point sources, such as wastewater treatment plants (Petrie et al., 2015), as well as the need of wastewater reuse, due to the lack of fresh water sources (Fatta Kassinos, 2015), have been stimulating the discussion in the last years about new relevant regulations (JRC, 2015; Brack et al., 2017) to make urban wastewater treatment plants (UWTPs) effluents safer. As matter of fact, because of inconsistent national legislation across Member States, the European Commission is working to a legislative proposal on minimum quality requirements $(\mathrm{MQR})$ for water reuse in agricultural irrigation and aquifer recharge (Rizzo et al., 2018). Meanwhile, in the attempt to minimize the release of micro-contaminants (also known as contaminants of emerging concern, CECs) from UWTPs in the environment, Switzerland enacted a regulation entered into force on January 2016, which requires the upgrade of UWTPs within the next twenty years (www.bafu.admin.ch). Accordingly, a selection of CECs from a list of twelve compounds need to be removed by 80\% (Bourgin et al. 2018). The increasing interest toward CECs and other emerging contaminants, such as antibiotic resistant bacteria (ARB) and genes (ARGs), as well as the ongoing discussion on new related regulations, are driven the attention on UWTPs that are not or poorly effective to successfully address these new challenges (Rizzo et al., 2013; Petrie et al., 2015; Krzeminski et al., 2019). In a multi-barrier approach, typically implemented in UWTPs trains, the most important role to minimize the release of CECs and the risk of antibiotic resistance spread into the environment relies on tertiary treatment (Ferro et al., 2015; Bourgin et al. 2018). Unfortunately, consolidated tertiary treatments either did not show to be effective or did result in some drawbacks. As matter of fact, chlorination, typically used as disinfection step before UWTP effluent disposal or reuse, is poorly effective in the removal of CECs (Fu et al., 2018) and in controlling antibiotic resistance (Fiorentino et al., 2015; Yuan et al., 2015), as well as results in the formation of 
hazardous disinfection by-products (DBPs) (Huang et al., 2016; Keun-Young et al., 2016). $\mathrm{UV}-\mathrm{C}$ disinfection is effective in the inactivation of pathogens when sand filtration is used as pre-treatment, but poor or not effective at all (depending on the characteristics of the target molecule) in the removal of CECs (Lian et al., 2015). Tertiary treatment by ozonation can inactivate pathogens and remove CECs, but an additional post-treatment step can be necessary to remove ozonation by products (i.e., nitrosodimetylamine and bromate) (Hollender et al., 2009). Activated carbon adsorption is also an effective tertiary treatment for the removal of CECs (Rizzo et al., 2015; Ahmed, 2017) but an additional disinfection process may be necessary, in particular to meet more stringent standards for wastewater reuse. Due to their efficiency in the removal of CECs and inactivation of pathogens because of the formation of reactive oxygen species (ROS), such as hydroxyl radicals $\left(\mathrm{HO}^{\circ}\right)$, advanced oxidation processes (AOPs) represent a possible alternative to conventional tertiary treatments. AOPs can be classified in different ways, one being photo (among which $\mathrm{UV} / \mathrm{H}_{2} \mathrm{O}_{2}$, photo-Fenton and $\mathrm{TiO}_{2}$ photocatalysis) and not photo (such as Fenton, $\mathrm{O}_{3}, \mathrm{O}_{3} / \mathrm{H}_{2} \mathrm{O}_{2}$ etc.) driven AOPs. Photo driven AOPs, can be also operated with solar radiation to save energy costs (Malato et al., 2009). Homogeneous photo driven AOPs (such as $\mathrm{UV} / \mathrm{H}_{2} \mathrm{O}_{2}$ and photo-Fenton) are more attractive than heterogeneous photocatalytic processes (such as $\mathrm{UV} / \mathrm{TiO}_{2}$ ) for short term application as tertiary treatment method of urban wastewater. As matter of fact, the technology of heterogeneous processes is not yet fully mature for large scale applications, basically for limitations related either to catalyst removal after treatment or fixing catalyst on a support (Sacco et al., 2018), and it would be more expensive than homogeneous photo driven AOPs based technology. Peracetic acid (PAA) is increasingly used as alternative option to chlorination in wastewater disinfection (Antonelli et al., 2013; Formisano et al., 2016). However, disinfection efficiency (Formisano et al., 2016) and CECs removal (Cai et al., 2017) may be improved by coupling PAA with UV radiation, due to the formation of $\mathrm{HO}^{\bullet}$. 
91 Accordingly, it is worthy of investigation possible use of this process as homogeneous 92 photo driven AOP for tertiary treatment of urban wastewater. In particular, before possible upscale it would be of interest to learn process efficiency in the removal of CECs at environmentally significant concentrations as well as its effect on antibiotic resistance. Accordingly, in the present work, UV/PAA process at pilot scale was investigated for the first time in the inactivation of an antibiotic resistant (AR) (sulfamethoxazole) Escherichia coli (E. coli) strain, and in the degradation of a mixture of three CECs: (anticonvulsant) Carbamazepine (CBZ), (analgesic) Diclofenac (DCF) and (antibiotic) Sulfamethoxazole (SMX), at initial concentration of $100 \mu \mathrm{gL}^{-1}$ each, in a lower complexity aqueous matrix (namely groundwater $(\mathrm{GW})$ ). Subsequently, UV/PAA process was investigated in wastewater (WW) treatment for the inactivation of indigenous AR E. coli and the degradation of the same mixture of CECs. The effect of light source (solar light Vs UV-C radiation) was also investigated in both aqueous matrices (GW and WW). E. coli was chosen as model microorganism because it is considered among the most important vectors in the dissemination of antimicrobial resistance in the environment (Rizzo et al., 2013) as well as because it is used as pathogen indicator in regulations and guide lines for wastewater disposal and reuse (USEPA, 2012; ISO, 2015). CBZ, DCF and SMX were selected as model CECs because typically detected in urban wastewater (Petrie et al., 2015).

\section{Material and methods}

\subsection{Chemicals}

Carbamazepine (CBZ), Diclofenac (DCF) and Sulfamethoxazole (SMX), all high purity grade (>99\%), were purchased from Sigma-Aldrich. Peracetic Acid (PAA) solution, containing $30 \% \mathrm{w} / \mathrm{w}$ of PAA and $4.5 \% \mathrm{w} / \mathrm{w}$ of $\mathrm{H}_{2} \mathrm{O}_{2}$ was purchased from Sigma-Aldrich 
116 and used as obtained. Sodium thiosulfate $\left(\mathrm{Na}_{2} \mathrm{~S}_{2} \mathrm{O}_{3}, 99 \% \mathrm{w} / \mathrm{w}\right)$ and bovin liver catalase

117 were used, as received from Sigma-Aldrich. Titanium IV oxysulfate (Riedel-de-Haën, 118 Germany) was used, as obtained from the manufacturer.

121 To evaluate water matrix effect on UV/PAA process tests were performed with both GW and wastewater WW. GW was collected from a borehole located on the PSA site with depth of approximately $200 \mathrm{~m}$. Physical-chemical characteristics of both water matrices are given in Table 1.

128 GW samples were inoculated with SMX resistant E. coli strain selected from the effluent 129 of the biological process (activated sludge) of Almeria (Spain) UWTP, according to the 130 procedure explained in the subsequent paragraph 2.4. WW samples were taken from the 131 same UWTP during spring-summer time (June-August 2017), at the same location and used for disinfection/oxidation experiments without inoculum. Samples were collected in amber glass bottles and stored at $4{ }^{\circ} \mathrm{C}$ for a maximum of two days.

\subsection{AOPs and control experiments}

136 Experimental design included two pilot scale reactors namely a Compound Parabolic 137 Collector (CPC) for outdoor sunlight experiments and UV-C reactor (UVC). 
The CPC reactor used was previously described (Polo-López et al., 2010). Briefly, it

141 consists of two $60 \mathrm{~L}$ tube modules, each one equipped with 10 cylindrical glass tubes made

142 of borosilicate glass, with a diameter of $5 \mathrm{~cm}$, a length of $150 \mathrm{~cm}$ and a thickness of 2.5

$143 \mathrm{~mm}$, to allow a 90\% transmission of UVA in the natural solar spectrum. The photoreactor

144 is titled at $37^{\circ}$ with respect to the horizontal to maximize solar radiation. A tank housed in

145 the lower part of the pilot plant is connected to a pump, which allowed to operate the

146 modules in a recirculation mode. The CPC reactor has a total illuminated volume of $45 \mathrm{~L}$

147 and it was operated with a water flow rate of $30 \mathrm{Lmin}^{-1}$. This flow rate guarantees a

148 turbulent regime, which results in a proper homogenization of water samples and in a good

149 contact between bacteria, contaminants and oxidant. Disinfection experiments were carried 150 out during 300 minutes of solar exposure on clear sunny days at PSA from May 2017 to

151 August 2017. More specifically, firstly the solar photoreactor was filled in with $60 \mathrm{~L}$ of

152 water matrix (GW or RW) and then, the mixture of the three CECs $\left(100 \mu \mathrm{gL}^{-1}\right.$ of initial 153 concentration each) and the sulfamethoxazole resistant E.coli solution $\left(10^{6} \mathrm{CFU} \mathrm{mL}{ }^{-1}\right.$

154 initial bacterial density) were spiked in. After 5 minute of homogenization with the CPC 155 still covered, control sample was taken in order to ensure the presence of bacteria and 156 contaminants. Then, PAA was added to the reactor tank and after 10 minute of 157 recirculation, the experiment started as the cover was removed. Samples were collected at 158 regular intervals depending on the treatment. Water temperature ranged from 21.0 to 47.7

$159{ }^{\circ} \mathrm{C}$ and $\mathrm{pH}$ ranged from 8.04 to 9.41. A fixed pyranometer (Model CUV5, 280-400 nm, 160 Kipp \& Zonen, Netherlands) registered in continuous the incident light. The inactivation and degradation rates were plotted as a function of both the experimental time $(\mathrm{t})$ and the cumulative energy per unit of volume ( $\left.\mathrm{Q}_{\mathrm{UV}}\right)$ received in the photoreactor, commonly used 
163 to compare results under different condition (Malato et al., 2009), and calculated by 164 Equation (1):

165

$\mathrm{QUV}_{\mathrm{U}, \mathrm{n}}=\mathrm{QUV}, \mathrm{n}-1+\Delta \mathrm{t}_{\mathrm{n}} \cdot \mathrm{UV}_{\mathrm{G}, \mathrm{n}} \cdot \mathrm{A}_{\mathrm{r}} / \mathrm{V}_{\mathrm{t}} \quad \Delta \mathrm{t}_{\mathrm{n}}=\mathrm{t}_{\mathrm{n}}-\mathrm{t}_{\mathrm{n}-1}$

166 where $\mathrm{QUV}_{\mathrm{UV}, \mathrm{n}}$ and $\mathrm{Q}_{\mathrm{UV}, \mathrm{n}-1}$ is the UV energy accumulated per liter $\left(\mathrm{kJ} \mathrm{L}^{-1}\right)$ at times $\mathrm{n}$ and $\mathrm{n}-1$, $167 \mathrm{UV}_{\mathrm{G}, \mathrm{n}}$ is the average incident radiation on the irradiated area, $\Delta \mathrm{t}_{\mathrm{n}}$ is the experimental time 168 of sample, $A_{r}$ is the illuminated area of the reactor $\left(\mathrm{m}^{2}\right)$ and $V_{t}$ is the total volume of water 169 treated (L). Each experiment was performed in duplicate, between 10 am to $16 \mathrm{pm}$ local 170 time, and the results were plotted as the average of the two replicates.

\subsubsection{UVC plant}

173 The UVC reactor is a plant equipped with three UVC lamps (254 nm peak wavelengths, $230 \mathrm{~W}$ ) connected in series, with a flexible configuration that allow the system to operate with a single lamp, two or three lamps in recirculating batch mode or continuous flow mode. In this study, only one lamp was used and the illuminated volume was $4.17 \mathrm{~L}$, which corresponds to a total volume in the plant of $80 \mathrm{~L}$. Disinfection/oxidation experiments were carried out during 180 minutes at PSA from May 2017 to August 2017. More specifically, firstly the reactor was filled in with water matrix $(\mathrm{GW}$ or $\mathrm{WW})$ and then, the mixture of the three CECs $\left(100 \mu \mathrm{gL}^{-1}\right)$ and the sulfamethoxazole resistant E.coli solution $\left(10^{6} \mathrm{CFUmL}^{-1}\right)$ were spiked in. After 15 minute of homogenization, with the lamp still switched off, initial sample was taken in order to ensure the presence of bacteria and contaminants. Then, PAA was added to the reactor tank and after 15 minute of recirculation, the experiment started and the lamp was switched on. Samples were collected at regular intervals depending on the treatment. A fixed controller (ProMinent) housed in the back of the reactor, monitored in continuous water flow rate $\left(46 \mathrm{Lmin}^{-1}\right)$ and UVC lamp intensity $\left(33.7 \mathrm{Wm}^{-2}\right.$ for WW 
187

188

189

190

191

192

193

194

195

196

197

198

199

200

201

202

203

204

205

206

207

208

209

210

and $99.7 \mathrm{Wm}^{-2}$ for $\left.\mathrm{GW}\right)$. The equipment registers, in continuous during the test, the sensor measurements in terms of incident irradiation $\left(\mathrm{Wm}^{-2}\right)$, which is the UVC radiation energy rate incident on a surface per unit area. The accumulated energy was calculated according to Eq. 2:

$$
\operatorname{QuvC}_{\text {U }}\left(k J L^{-1}\right)=\operatorname{Dose}\left(\mathrm{Jm}^{-2}\right) \cdot A_{\mathrm{i}} / V_{\mathrm{T}}\left(m^{2} L^{-1}\right)\left(k J(1000 J)^{-1}\right)
$$

where QUVC is the accumulated UVC energy per L, Dose is the UVC ultraviolet irradiation $\left(\mathrm{Wm}^{-2}\right)$ emitted by the lamp multiplied by the illumination time, $\mathrm{A}_{\mathrm{i}}\left(0.28 \mathrm{~m}^{2}\right)$ is the irradiated surface, $\mathrm{V}_{\mathrm{T}}(80 \mathrm{~L})$ is the total volume of the water into the pilot plant and $\mathrm{Vi}$ $(4.17 \mathrm{~L})$ is the total irradiated volume. Each experiment was performed in duplicate and the results were plotted as the average of the two replicates.

\subsection{Selection of antibiotic resistant E. coli strain}

The antibiotic resistant E.coli strain inoculated in GW for disinfection experiments was isolated from the effluent of the biological process (activated sludge) of Almeria UWTP by membrane filtration method and subsequent cultivation on selective medium, according to a previously published procedure (Rizzo et al., 2014). More specifically, $50 \mathrm{~mL}$ of wastewater and its serial dilutions were filtered through sterile membranes (cellulose nitrate, $0.45-\mu \mathrm{m}$ pore size, $47 \mathrm{~mm}$ diameter, Millipore) which were incubated $\left(24 \mathrm{~h}, 37^{\circ} \mathrm{C}\right)$ on AR m-FC (Difco) culture medium supplemented with $64 \mathrm{mgL}^{-1}$ of sulfamethoxazole. Antibiotic concentration was chosen according to the double of the respective minimum inhibitory concentration (MIC) values available in EUCAST database (2014). Some colonies were randomly picked up and frozen at $-5{ }^{\circ} \mathrm{C}$ using sterile vials of cryobeads (Deltalab). To recover the stock, the vial was slowly unfreezed up to reach room temperature $\left(25^{\circ} \mathrm{C}\right)$. One bead was streaked onto a Petri dish of AR m-FC agar and 
211 incubated for $20 \mathrm{~h}$ at $37^{\circ} \mathrm{C}$ to obtain isolated bacteria colonies. This dish was stored during

2121 week in the refrigerator to prepare a fresh E. coli culture to make it available for GW

213 disinfection/oxidation experiments. Fresh liquid cultures were prepared taking one colony

214 from the refrigerated stock in the Petri dish using a loop, transferred into $14 \mathrm{~mL}$ of liquid

215 LB broth and incubated in a rotary shaker at $100 \mathrm{rpm}$, during $18-20 \mathrm{~h}$ at $37^{\circ} \mathrm{C}$ to get the 216 bacterial stationary phase concentration $\left(10^{9} \mathrm{CFU} \mathrm{mL}^{-1}\right)$. Bacterial suspensions were 217 harvested by centrifugation at $3000 \mathrm{rpm}$ for $10 \mathrm{~min}$. Then, the pellet was re-suspended in 218 Phosphate Buffer Saline (PBS) solution and diluted directly into the GW sample for each 219 experiment to reach the initial concentration of $10^{6} \mathrm{CFUmL}^{-1}$.

\subsection{Analytical measurements}

222 Before performing each experiment, water samples were characterized in terms of 223 temperature, $\mathrm{pH}$, conductivity, DOC, inorganic carbon (IC), total carbon (TC), anions and cations. Temperature and $\mathrm{pH}$ were measured using a multi parametric sensor WTW multi720. Conductivity was measured by a conductivity meter GLP31 CRISON. Turbidity was measured by a turbidity meter 2100AN model (Hach). DOC, IC and TC were analyzed using a Shimadzu TOC-V-CSN and an auto-sampler ASI-V. DOC was estimated as the difference between the TC and the IC values. Samples were filtered with a $0.22 \mathrm{~mm}$ nylon filter (Aisimo, Millipore Millex ${ }^{\circledR}$ GN) before their injection into the equipment. The calibration was performed periodically with potassium hydrogen phthalate in Milli-Q water for TC and a sodium carbonate/sodium bicarbonate (1:1) for IC. Anions and cations were analyzed using ion chromatography, 850 Professional IC - Cation coupled to Metrohm 872 Extension Module. Samples were filtered with a $0.22 \mathrm{~mm}$ nylon filter (Aisimo) before injection into the equipment. The calibration was checked before samples measurements 
were monitored by ultra-performance liquid chromatography UPLC (Agilent

237 Technologies, series 1200) with a UV-DAD detector and a C-18 analytical column. The

238

239

240

241

242

243

244

245

246

$247 \mathrm{H}_{2} \mathrm{O}_{2}$ concentration was measured with a spectrophotometer (PG Instruments Ltd T-60-U)

248 at $410 \mathrm{~nm}$ in glass cuvettes with a $1 \mathrm{~cm}$ of path length based on the formation of a yellow

249 complex from the reaction of titanium IV oxysulfate with $\mathrm{H}_{2} \mathrm{O}_{2}$ following DIN $38409 \mathrm{H} 15$.

250 Absorbance was read after 5 min incubation time against a $\mathrm{H}_{2} \mathrm{O}_{2}$ standard curve linear in 251

252

253

254

255

256

257

initial conditions were 95\% water with $25 \mathrm{mM}$ formic acid (A) and 5\% $\mathrm{ACN}(\mathrm{B})$. A linear gradient progressed from $10 \%$ to $0 \% \mathrm{~B}$ in $15 \mathrm{~min}$. Re-equilibration time was 3 min with a flow rate of $1 \mathrm{~mL} \cdot \mathrm{min}^{-1}$. In order to prepare the vial for the detector, firstly, $4.5 \mathrm{~mL}$ of sample were filtered using a $0.22-\mu \mathrm{m}$ PTFE filter (Millipore). Then, to remove any adsorbed compounds, the filter was washed with $2.5 \mathrm{~mL}$ of $\mathrm{ACN}$ mixed with the filtered water sample. The prepared solution was transferred into an amber glass vial, put in the UPLC and analyzed using an injection volume of $100 \mu \mathrm{L}$. Retention time, quantification limit (LOQ), detection limits (LOD) and maximum absorption (1) for the MCs are shown in Table S1 (in supplementary information file). the $0.1-100 \mathrm{mgL}^{-1}$ concentration range.

PAA concentration was measured according to the method from HACH (2014). Briefly, $2.5 \mathrm{ml}$ of sample was mixed with $15 \mathrm{mg}$ of N,N-diethyl-p-phenylenediamine (DPD, VWR Chemicals). Absorbance was measured with a spectrophotometer (PG Instruments Ltd T$60-\mathrm{U}$ ) at $530 \mathrm{~nm}$ after 45 seconds of incubation time against a PAA standard curve (range $\left.0.05-5 \mathrm{mg} \mathrm{L}^{-1}\right)$ 
259 Bacterial count was performed by standard plate counting method through a serial 10 -fold 260 dilutions in PBS placed into AR m-FC agar Petri dishes. In particular, when the bacterial 261 load was expected to be high, $50 \mathrm{~mL}$ drop of adequate dilution was plated, instead, when 262 the bacterial load was expected to be low, volume of $500 \mathrm{~mL}$ was spread onto prepared 263 dishes. Antibiotic resistant (AR) E.coli colonies were counted after an incubation period of $26420 \mathrm{~h}$ at $37^{\circ} \mathrm{C}$ (detection limit (DL) $2 \mathrm{CFUmL}^{-1}$ ). Measurements were carried out in 265 duplicates in order to plot average values. The results were highly reproducible and the 266 standard deviation of the replicates is showed in the graphs as error bars. Stock solutions of

267 bovine liver catalase $\left(50 \mathrm{mg} \mathrm{L}^{-1}\right)$ and sodium thiosulfate $\left(100 \mathrm{mg} \mathrm{L}^{-1}\right)$ were freshly 268 prepared every day and added $20 \mu \mathrm{L} \mathrm{mL}^{-1}$ and $1 \mu \mathrm{L} \mathrm{mL}^{-1}$ respectively to all water samples taken from the reactors in order to remove any residual concentration of PAA and $\mathrm{H}_{2} \mathrm{O}_{2}$.

\section{Results}

\subsection{Inactivation of AR E. coli by sunlight/PAA in CPC}

\subsubsection{Control tests}

274 Control experiments were performed with PAA and sunlight as standalone processes, 275 respectively. The effect of PAA on the inactivation of AR E. coli under dark conditions 276 was investigated for three PAA concentrations $\left(0.075,1\right.$ and $\left.2 \mathrm{mg} \mathrm{L}^{-1}\right)$ in GW. The DL was 277 achieved for 1 and $2 \mathrm{mg}$ PAA L ${ }^{-1}$, with 4 and $5 \log$ unit inactivation respectively, after 15 278 min (Figure 1). The lower investigated dose $\left(0.075 \mathrm{mg} \mathrm{PAA} \mathrm{L}^{-1}\right)$ resulted only in half $\log$ 279 unit inactivation after $180 \mathrm{~min}$, possibly due to the low initial concentration of both PAA 280 and $\mathrm{H}_{2} \mathrm{O}_{2}\left(0.039 \mathrm{mg} \mathrm{L}^{-1}\right)$. The DL was even achieved for sunlight experiment, but after 300 281 minutes treatment $\left(53.67 \mathrm{kJL}^{-1}\right)$. 
285 Part of PAA initial concentration was consumed as the oxidant solution was added to GW sample; as can be observed from Figure SI1, PAA concentration measured just after the addition of PAA solution $(\mathrm{t}=0)$ is lower than the corresponding initial concentration dosed. Moreover, PAA was almost totally consumed after 300 min treatment when $1 \mathrm{mg}$ PAA L $^{-1}$ was added; while only $50 \%$ was consumed when initial PAA was 2 mg PAA L ${ }^{-1}$.

\subsubsection{Effect of PAA initial concentration}

292 Since AR E. coli inactivation was quite fast between 1 and $2 \mathrm{mg} \mathrm{PAA} \mathrm{L}^{-1}$ under dark 293 conditions, lower PAA concentrations (in the range $0.075-1.0 \mathrm{mg} \mathrm{L}^{-1}$ ) were investigated 294 during sunlight/PAA tests. QUv and solar exposure time required to reach the DL for the inactivation of AR E.coli, decreased as PAA dose was increased. More specifically, in GW the best performance was achieved after 30 minutes with $0.2 \mathrm{mg} \mathrm{PAA} \mathrm{L}-1$ (Quv $=4.40 \mathrm{kJL}^{-}$

${ }^{1}$ ) (Figure 2a). Inactivation rates were faster compared to sunlight experiment where DL was achieved after 300 minutes treatment with a higher energy requirement $\left(53.67 \mathrm{kJL}^{-1}\right)$.

\section{Figure 2}

302 Moreover, the lower investigated PAA initial concentration $\left(0.075 \mathrm{mg} \mathrm{L}^{-1}\right)$ did not produce 303 a sufficient amount of hydroxyl radicals to improve AR E.coli inactivation compared to 
solar radiation as standalone process. PAA was almost totally consumed during treatment 305 process (Figure SI2a) and a fluctuation in residual $\mathrm{H}_{2} \mathrm{O}_{2}$ concentration $\left(1 \mathrm{mg}\right.$ PAA L ${ }^{-1}$ solution) was observed (Figure SI2b).

307 The effect of sunlight/PAA process was also investigated in WW (Figure 2b). WW was not 308 inoculated with the selected AR E. coli strain, therefore the inactivation curves refer to the 309 indigenous E. coli population resistant to SMX (initial bacterial density 70-7000 CFU mL

$31{ }^{1}$ ). In particular, different initial PAA concentrations $\left(1,2,4\right.$ and $\left.10 \mathrm{mg} \mathrm{L}^{-1}\right)$ were 311 investigated and the best performance was observed for $10 \mathrm{mg} \mathrm{PAA} \mathrm{L}^{-1}$ being the DL 312 achieved after 2 minutes irradiation $\left(\mathrm{Q}_{\mathrm{Uv}}=0.28 \mathrm{kJL}^{-1}\right)$ (Figure 2b). The DL was achieved 313 for all the investigated conditions, being the sunlight process the slower $\left(Q_{U V}=38.03 \mathrm{~kJ} \mathrm{~L}^{-1}\right.$ 314 after $210 \mathrm{~min}$ ). According to the results achieved in GW experiments, PAA was almost 315 totally consumed during treatment process in WW too and only when a higher dose (20 mg $316 \mathrm{~L}^{-1}$ ) was investigated (to evaluate possible effect on CECs degradation) a residual was 317 detected (Figure SI3a). Fluctuation in residual $\mathrm{H}_{2} \mathrm{O}_{2}$ concentration (1 mg PAA L ${ }^{-1}$ solution) 318 was also observed in WW experiments (Figure SI3b).

\subsection{Degradation of CECs by sunlight/PAA in CPC}

321 Typically, when AOPs are investigated in the removal of pollutants from water, a matrix 322 effect can be observed, with a decreased process efficiency as the complexity of the aqueous matrix increases (e.g., from deionized water solutions to GW and WW). The decreased efficiency can be typically explained by the occurrence of easy to oxidize molecules (also known as oxidant demand of the target water matrix) in more complex water matrices compared to less complex ones. Actually, this behaviour was not evident in 
327 the removal of $\mathrm{CBZ}$ and DCF by sunlight/PAA, while it was evident for SMX, as 328 explained in the subsequent paragraphs.

329

330

3.2.1 Control tests

331 Control experiments to evaluate the effect of PAA and sunlight as standalone processes, on 332 the target CECs were also carried out. In particular, the effect of PAA dose in darkness was

333 investigated at $2 \mathrm{mg} \mathrm{L}^{-1}$ initial concentrations (Figure 3).

334

335

Figure 3

336

337 Unlike of CBZ, DCF was effectively oxidized by PAA after 60 minutes ( $80 \%$ removal),

338 while SMX was removed at a lower rate $(52 \%$ after $300 \mathrm{~min})$ compared to DCF.

339 Photodegradation rate by sunlight as standalone process changed depending on the target

340 CEC: from no degradation for CBZ, to moderate degradation for SMX (43\% after 300 min

341 irradiation and $\left.53.7 \mathrm{~kJ} \mathrm{~L}^{-1}\right)$, to high degradation for DCF (90\% after $180 \mathrm{~min}$ and $30.2 \mathrm{~kJ} \mathrm{~L}^{-}$

$\left.342^{1}\right)$.

343

344 3.2.2 Effect of PAA initial concentration

345 The effect of sunlight/PAA process on CECs was investigated for both water matrices

346 (GW and WW). CBZ was refractory to sunlight/PAA process too. Only when initial PAA

347 concentration was increased to $10 \mathrm{mg} \mathrm{L}^{-1}$ a significant degradation (40\%) was observed

348 after 300 min treatment $\left(\mathrm{Q}_{\mathrm{UV}}=55.53 \mathrm{~kJ} \mathrm{~L}^{-1}\right)$ in $\mathrm{GW}$ (Figure $\left.4 \mathrm{a}\right)$. 
352 Even for DCF, sunlight/PAA process enhanced degradation compared to PAA as 353 standalone process in GW matrix. The best performance was observed with $2 \mathrm{mg} \mathrm{PAA} \mathrm{L}^{-1}$ 354 that allowed to reach the quantification limit (QL) at $\mathrm{Q}_{\mathrm{Uv}}=10.23 \mathrm{~kJ} \mathrm{~L}^{-1}$ (Figure $4 \mathrm{~b}$ ). 355 Interestingly, as PAA concentration was further increased from 4 to $10 \mathrm{mg} \mathrm{L}^{-1}$, DCF 356 degradation rate decreased. Similar behaviour was observed for SMX (Figure 4c). SMX 357 degradation increased as PAA dose was increased from the lower dose $\left(0.075 \mathrm{mg} \mathrm{L}^{-1}\right)$ to 4 $358 \mathrm{mg} \mathrm{L}^{-1}$ (the QL was reached after $60 \mathrm{~min}$ and $\mathrm{Quv}_{\mathrm{UV}}=9.49 \mathrm{~kJ} \mathrm{~L}^{-1}$ ) then started to decrease, 359 although to a lower rate compared to DCF.

360 Due to the higher oxidant demand of WW, PAA doses lower than $1.0 \mathrm{mg} \mathrm{L}^{-1}$ were not 361 investigated and $20 \mathrm{mg}$ PAA L ${ }^{-1}$ was added (Figure 5). The behaviour of sunlight/PAA process in WW matrix was quite different compared to GW. As matter of fact, a moderate efficiency in CBZ degradation was also observed at lower PAA doses; for example $2 \mathrm{mg}$ $\mathrm{PAA} \mathrm{L}^{-1}$ resulted in $23 \% \mathrm{CBZ}$ degradation after $300 \min \left(\mathrm{Q}_{\mathrm{UV}}=58.39 \mathrm{~kJ} \mathrm{~L}^{-1}\right)$ and process efficiency increased as initial PAA concentration was increased to 4 and $10 \mathrm{mg} \mathrm{L}^{-1}$, being the best removal $(56 \%)$ observed with $10 \mathrm{mg}^{\mathrm{PAA} \mathrm{L}}{ }^{-1}$ after 300 minutes $\left(\mathrm{Q}_{\mathrm{UV}}=58.39 \mathrm{~kJ} \mathrm{~L}^{-}\right.$ $\left.{ }^{1}\right)$ (Figure 5a). But as PAA was further increased $\left(20 \mathrm{mg} \mathrm{L}^{-1}\right)$, process efficiency drastically decreased, thus showing a similar behaviour to DCF and SMX in GW experiments. 
372 DCF degradation was drastically affected by aqueous matrix. The best performance in

373 WW was observed with $20 \mathrm{mg} \mathrm{PAA} \mathrm{L}^{-1}$ that reached the QL after $120 \mathrm{~min}\left(\mathrm{Q}_{\mathrm{UV}}=11.46 \mathrm{~kJ}\right.$

$374 \mathrm{~L}^{-1}$ ) (Figure 5b). Moreover, aqueous matrix significantly affected process efficiency at 375 lower PAA concentrations; for example, only $32 \%$ degradation was achieved with $2 \mathrm{mgL}^{-1}$ 376 of PAA in WW, compared to $99 \%$ observed in GW after 60 min treatment $\left(\mathrm{Q}_{\mathrm{UV}}=10.23 \mathrm{~kJ}\right.$

$377 \mathrm{~L}^{-1}$ ). Similarly to the results observed for GW, SMX degradation by sunlight/PAA 378 increased as PAA concentration was increased (Figure 5c). The QL was achieved for 10 $379 \mathrm{mg} \mathrm{L}^{-1}$ of PAA after $240 \mathrm{~min}\left(\mathrm{Quv}_{\mathrm{UV}}=46.03 \mathrm{~kJ} \mathrm{~L}^{-1}\right)$. But a further increase of initial PAA 380 dose to $20 \mathrm{mg} \mathrm{L}^{-1}$ resulted in a decreased degradation efficiency, thus confirming the trend 381 already observed in GW experiments.

\subsection{Inactivation of AR E. coli by UV-C/PAA process}

384 Really fast inactivation rates were observed in GW for UV-C/PAA process compared to 385 sunlight/PAA (Figure 6). The detection limit was achieved for all PAA investigated doses and even for UV-C as standalone process. In particular, total inactivation was achieved in a few minutes for $0.15 \mathrm{mg} \mathrm{PAA} \mathrm{L}{ }^{-1}(2 \mathrm{~min})$ and $0.2 \mathrm{mg} \mathrm{PAA} \mathrm{L}^{-1}(4 \mathrm{~min})$, but it is worthy to mention that the initial AR E. coli concentrations were really low (47 and $240 \mathrm{CFU} \mathrm{mL}^{-1}$, respectively).

\section{Figure 6}

393 With $0.075 \mathrm{mg} \mathrm{L}^{-1}$ and $0.1 \mathrm{mgL}^{-1}$ of PAA DL was reached with a cumulative energy dose of $67.39 \mathrm{kJL}^{-1}$ (180 min irradiation) and $33.93 \mathrm{kJL}^{-1}$ (90 min irradiation), respectively. 
395 Due to both the higher oxidant demand of WW compared to GW and the total 396 consumption of PAA and $\mathrm{H}_{2} \mathrm{O}_{2}$ in $\mathrm{GW}$ experiments, higher concentrations of PAA (4, 10 397 and $20 \mathrm{mgL}^{-1}$ ) were investigated in UV-C/PAA experiments in WW. Even in this case the 398 initial AR E. coli concentrations were really low $\left(63,35\right.$ and 2 CFU mL ${ }^{-1}$ for 4,10 and 20 399 mg PAA L ${ }^{-1}$ experiments, respectively) and the DL was achieved in 2 and 15 min for 10 400 and $4 \mathrm{mg} \mathrm{PAA} \mathrm{L}^{-1}$ experiments, respectively (data not shown).

\subsection{Degradation of CECs by $U V-C / P A A$ process}

403

404

406

407

408

409

410

411

412

413

414 For the lower concentration investigated in WW (4 mg PAA L $\left.{ }^{-1}\right)$ the aqueous matrix effect 415 between GW and WW was not observed (Figure 7b). But when PAA concentration was 416 increased (10 and $20 \mathrm{mg} \mathrm{PAA} \mathrm{L}^{-1}$ ) the difference between the two matrices increased (e.g., $41755 \%$ CBZ removal in WW compared to $67 \%$ in GW for $10 \mathrm{mg} \mathrm{PAA} \mathrm{L}^{-1}$ at approximately

\section{Figure 7}


$\left.41821 \mathrm{~kJ} \mathrm{~L}^{-1}\right)$. Interestingly, at the higher investigated dose $\left(20 \mathrm{mg} \mathrm{PAA} \mathrm{L}^{-1}\right)$, the residual 419 concentration of PAA is lower than that one for $10 \mathrm{mg} \mathrm{PAA} \mathrm{L}^{-1}$ solution, but the 420 corresponding $\mathrm{H}_{2} \mathrm{O}_{2}$ residual concentration is significantly higher (Figure SI5).

421 The best degradation of DCF in GW was already observed for the lower investigated PAA 422 doses $\left(0.075 \mathrm{mg}\right.$ PAA $\left.\mathrm{L}^{-1}\right)$ compared to sunlight/PAA tests (Figure 8a). Even in UV$423 \mathrm{C} / \mathrm{PAA}$ tests, process efficiency started to decrease above a certain concentration (1.0 mg $424 \mathrm{~L}^{-1}$ ) of PAA, being the worst removal observed for the higher investigated PAA dose (10 $425 \mathrm{mg} \mathrm{L} \mathrm{L}^{-1}$ ). The water matrix affected the photo-oxidation process, because no drastic 426 efficiency decrease was observed as PAA was increased (Figure 8b).

\section{Figure 8}

SMX was effectively degraded even with UV-C as stand-alone process in GW (DL was

431 achieved with $\mathrm{Q}_{\mathrm{UV}}=5.78 \mathrm{~kJ} \mathrm{~L}^{-1}$ ) and WW (DL observed for $\mathrm{Q}_{\mathrm{UV}}<4.58 \mathrm{~kJ} \mathrm{~L}^{-1}$ ), accordingly 432 PAA addition did not significantly improve process efficiency (for $4 \mathrm{mg} \mathrm{PAA} \mathrm{L}^{-1} \mathrm{DL}$ 433 observed for $\mathrm{Q}_{\mathrm{UV}}<2.4 \mathrm{~kJ} \mathrm{~L}^{-1}$ ) (data not shown).

\section{Discussion}

\subsection{Photolysis of PAA and effect on PAA and $\mathrm{H}_{2} \mathrm{O}_{2}$ concentrations}

437 UV/PAA process has been poorly investigated so far, and the previous works have been basically focused on bacteria inactivation (Koivunen and Heinonen-Tanski, 2005; de 
440 al., 2017). PAA $\left(\mathrm{CH}_{3} \mathrm{CO}_{3} \mathrm{H}\right)$ aqueous solutions commercially available are an equilibrium

441 mixture of acetic acid $\left(\mathrm{CH}_{3} \mathrm{COOH}\right), \mathrm{H}_{2} \mathrm{O}_{2}$, PAA and water, according to the reaction:

$442 \quad \mathrm{CH}_{3} \mathrm{COOH}+\mathrm{H}_{2} \mathrm{O}_{2} \leftrightarrow \mathrm{CH}_{3} \mathrm{CO}_{3} \mathrm{H}+\mathrm{H}_{2} \mathrm{O}($ Eq.3)

443 Photolysis of the $\mathrm{O}-\mathrm{O}$ bond in the PAA molecule results in the formation of $\mathrm{HO}^{\circ}$, 444 according to Equation 4 (Caretti and Lubello, 2003):

$445 \mathrm{CH}_{3} \mathrm{CO}_{3} \mathrm{H}+\mathrm{hv} \rightarrow \mathrm{CH}_{3} \mathrm{COO}^{\bullet}+\mathrm{HO}^{\bullet}($ Eq.4)

446 The $\mathrm{CH}_{3} \mathrm{COO}^{\circ}$ molecule will rapidly split in $\mathrm{CH}_{3}{ }^{\circ}$ and $\mathrm{CO}_{2}$ (Martin and Gehr, 2007).

447 Moreover, $\mathrm{HO}^{\bullet}$ molecules can also recombine to form $\mathrm{H}_{2} \mathrm{O}_{2}$ :

$448 \mathrm{HO}^{\bullet}+\mathrm{HO}^{\bullet} \rightarrow \mathrm{H}_{2} \mathrm{O}_{2}($ Eq.5)

449 The production of PAA (Eq.3) and the recombination of $\mathrm{HO}^{\bullet}$ molecules (Eq.5) can explain 450 the fluctuations observed in the measurement of residual $\mathrm{H}_{2} \mathrm{O}_{2}$ (Figure SI2b and SI3b).

451 According to the results achieved in this work, the mechanisms of bacterial inactivation 452 and CECs degradation in PAA photolysis are possible related to a combination of effects 453 including photolysis, oxidation (by PAA solution) and formation of $\mathrm{HO}^{\bullet}$.

\subsection{Control tests: effect of radiation and PAA solution on bacteria inactivation and} CECs degradation

The effect of sunlight and UV-C radiation on bacteria inactivation is evident from figures 2 and 6, respectively. To date, all waterborne pathogenic bacteria, among which E. coli, have been found to be amenable to sunlight disinfection (McGuigan et al., 2012). Although the

460 UV-A wavelengths are not sufficiently energetic to alter DNA directly, UV-A play an 461 important role in promoting the formation of intracellular reactive oxygen species (e.g., 
$462 \mathrm{HO}^{\circ}$ ) which can, in turn, damage DNA. UV-C radiation (200-280 $\mathrm{nm}$ germicidal 463 wavelength range, peaks at about 260-265 $\mathrm{nm}$ ) has a direct effect on bacterial cells 464 because it is absorbed by nucleic acids; cell inactivation can take place through UV465 induced damages such as the formation of pyrimidine dimers in their DNA (Kowalski, 466 2009).

467 While CBZ was not (under sunlight in GW) or poorly (under sunlight in WW and under 468 UV-C radiation) photodegraded, confirming its refractory behaviour to direct photolysis 469 (Calisto et al., 2011), SMX and DCF were significantly degraded under irradiation. DCF 470 has an absorbance peak at $275-280 \mathrm{~nm}$ and its degradation under sunlight is the result of 471 two mechanisms: direct photolysis and self-sensitization, being direct photolysis the main 472 one (Zhang et al., 2011). SMX absorbance spectrum is characterized by a peak at 257-268 $473 \mathrm{~nm}$ (depending on solution $\mathrm{pH}$ ) and tails well over $320 \mathrm{~nm}$, which overlap to solar 474 spectrum (in the 300-325 nm) and make its photodegradation possible (Trovò et al., 2009; 475 Rizzo et al., 2012).

476 The redox potential of PAA is comparable or even higher than many disinfectants (Zhang 477 et al., 2018), which make it effective in the inactivation of different bacterial populations. 478 Accordingly, our results in terms of AR E. coli inactivation under dark conditions (Figure 479 1) are consistent with previous results on E. coli inactivation (Antonelli et al., 2009). 480 Moreover, the high redox potential can also explain the high oxidation rate of DCF and 481 SMX (Figure 3). 

degradation

485

486

487

488

489

490

491

492

493

494

495

496

497

498

499

500

501

502

503

504

505

506

According to Eq.4, sunlight/PAA and UV-C/PAA processes result in the formation of $\mathrm{HO}^{\bullet}$ species. The role of $\mathrm{HO}^{\bullet}$ in the inactivation of E. coli was previously explained through the support of disinfection photocatalytic experiments (Cho et al. 2004). In subsequent studies, a killing mechanism where $\mathrm{HO}^{\bullet}$ progressively damages the cell surface structures leading to the release of intracellular material/molecules was proposed (Foster et al., 2011). Inactivation of microorganisms by photo driven advanced oxidation with PAA has been mainly investigated by using artificial light while, to our knowledge, only one study was specifically focused on sunlight/PAA process (Formisano et al., 2016) and no previous study evaluated the effect on the inactivation of AR E. coli. Formisano et al. (2016) observed a total inactivation of $E$. coli by sunlight/PAA $\left(8 \mathrm{mg} \mathrm{PAA} \mathrm{L}^{-1}\right)$ process after 120 minutes treatment $\left(\mathrm{Q}_{\mathrm{UV}}=7.42 \mathrm{~kJ} \mathrm{~L}^{-1}\right)$ in $\mathrm{WW}$, with an initial E. coli density as high as $10^{5}$ $\mathrm{CFU} \mathrm{mL} \mathrm{m}^{-1}$. These results are different compared to the inactivation rates observed in our work with (i) GW (where the best performance was achieved after 30 minutes with $0.2 \mathrm{mg}$ $\mathrm{PAA} \mathrm{L}^{-1}$ and $\mathrm{Q}_{\mathrm{UV}}=4.40 \mathrm{~kJ} \mathrm{~L}^{-1}$ ) (Figure 2a) and (ii) WW (being the best performance and DL achieved for $10 \mathrm{mg} \mathrm{PAA} \mathrm{L}^{-1}$ after 2 minutes irradiation and $\mathrm{Q}_{\mathrm{UV}}=0.28 \mathrm{~kJ} \mathrm{~L}^{-1}$ ) (Figure 2b). The different water matrix and E. coli population (total Vs AR E. coli) in case (i) and the lower initial bacterial density and the different $E$. coli population in case (ii) may explain the different results observed. Inactivation rates in GW drastically increased when UV-C radiation was used (DL achieved within 2 minutes for $0.15 \mathrm{mg} \mathrm{PAA} \mathrm{L}^{-1}$ and 4 minutes with $0.2 \mathrm{mg}$ PAA $\mathrm{L}^{-1}$ ) instead of sunlight. In WW experiments, the initial AR $E$. coli concentration was really low and the DL was achieved for all the PAA doses investigated. In a previous work on wastewater disinfection by UV-C/PAA process, E. coli 
507 inactivation of 3.6 and $4.5 \log$ units were observed for 2 and $4 \mathrm{mg} \mathrm{L}^{-1}$ of PAA, respectively 508 and an UV-C dose as high as UV dose of $120 \mathrm{~mW} \cdot \mathrm{s} \mathrm{cm}^{-2}$ (Lubello et al., 2002).

509 As the effect of photo driven AOPs with PAA on CECs degradation is of concern, it is 510 worthy to mention that scientific literature is lacking. However, our results are consistent 511 with removal trends of CBZ, DCF and SMX observed in solar driven AOPs (namely 512 photo-Fenton) (Klamerth et al., 2010; Ferro et al., 2015). In our work CBZ was found to be 513 refractory to sunlight/PAA process, according to the results available in the literature for 514 other solar driven AOPs. For example, only 36.9\% degradation (same initial CBZ 515 concentration) was observed after 300 minute sunlight $/ \mathrm{H}_{2} \mathrm{O}_{2}\left(20 \mathrm{mg} \mathrm{L} \mathrm{L}^{-1}\right)$ treatment $516\left(\mathrm{Q}_{\mathrm{UV}}=19.3 \mathrm{~kJ} \mathrm{~L}^{-1}\right)$ in WW (Ferro et al., 2015). When UV-C radiation was used as light 517 source in UV-C/PAA process, an higher efficiency was observed (77\% removal, $518 \mathrm{Q}_{\mathrm{UV}}=71,78 \mathrm{~kJ} \mathrm{~L}^{-1}$ ), but the removal efficiency (22\%) observed for $1 \mathrm{mg} \mathrm{PAA} \mathrm{L}^{-1}$ is not 519 consistent with previous work (90\% removal within $30 \mathrm{~min}$, CBZ initial concentration 1 $520 \mu \mathrm{M})$ (Cai et al., 2017). Unlike of CBZ, high removal efficiencies were observed for DCF and SMX in sunlight/PAA experiments, with significantly improved removals in UVC/PAA tests. However, DCF degradation was drastically affected by aqueous matrix, with a remarkable decreased efficiency in WW (Figure 5b) compared to GW (Figure 4b), in

524 particular at lower PAA concentrations. These results can be explained by the higher 525 oxidant demand of WW compared to GW (confirmed by the PAA and $\mathrm{H}_{2} \mathrm{O}_{2}$ consumption 526 for tests with low concentrations of PAA, Figures SI2 and SI3). Matrix effect was also 527 observed for SMX degradation by sunlight/PAA and its removal is consistent with previous works with other solar driven AOPs. As matter of fact, Karaolia et al. (2017)

529 observed complete removal of SMX (initial spiked concentration $100 \mu \mathrm{g} \mathrm{L}^{-1}$ ) by solar 530 photo-Fenton in urban wastewater in a $\mathrm{CPC}$ reactor $\left(50 \mathrm{mg} \mathrm{H}_{2} \mathrm{O}_{2} \mathrm{~L}^{-1}\right.$ and $5 \mathrm{mg} \mathrm{Fe} \mathrm{L}^{2+}$, 531119 min of normalized irradiation time $\left.\left(\mathrm{t}_{30 \mathrm{w}, \mathrm{n}}\right)\right)$. 
532 Interestingly, similar removal trends were observed for DCF and SMX in sunlight/PAA

533 experiments, in both water matrices investigated. The removal efficiency first increased as 534 initial PAA was increased, then started to decrease. Possibly, the reduced efficiency may 535 be due to the scavenging effect of PAA on $\mathrm{HO}^{\circ}$ because of the higher PAA concentration 536 (Cai et al., 2017).

\section{Conclusions}

539

540

541

542

543

544

545

546

547

548

\section{Acknowledgements}

554 The authors wish to thank European Commission for supporting Teresa Agovino's visit at

Photo driven AOP with PAA was investigated as possible tertiary treatment method of urban wastewater by evaluating its efficiency in the inactivation of AR E. coli and degradation of a mixture of three CECs under different light sources. Low PAA doses were found to be effective in the inactivation of AR E. coli, being UV-C driven process faster (DL achieved at $\mathrm{Q}_{\mathrm{Uv}}=0.3 \mathrm{~kJ} \mathrm{~L}^{-1}$ with $0.2 \mathrm{mg} \mathrm{PAA} \mathrm{L}^{-1}$ ) than solar driven one (DL achieved at $\mathrm{Q}_{\mathrm{UV}}=4.4 \mathrm{~kJ} \mathrm{~L}^{-1}$ with $0.2 \mathrm{mg} \mathrm{PAA} \mathrm{L}^{-1}$ ). Higher $\mathrm{Q}_{\mathrm{UV}}$ and PAA initial doses are necessary to effectively remove the target CECs (being CBZ the more refractory) and, although process efficiency in sunlight tests is lower compared to UV-C radiation, sunlight driven process is still an interesting option for small wastewater treatment plants taking into account that CECs occur at low concentrations (typically in the range $\mathrm{ng} \mathrm{L}^{-1}$ - fractions of $\mu \mathrm{g} \mathrm{L}^{-1}$ ). However, initial PAA dose should be optimized to find the best compromise between target bacteria inactivation and CECs removal as well as to prevent scavenging effect of PAA on $\mathrm{HO}^{\circ}$ because of high PAA concentration.

\footnotetext{
Plataforma Solar de Almeria in the context of ERASMUS programme.
} 


\section{$557 \quad$ References}

558 Ahmed, M. J., 2017. Adsorption of quinolone, tetracycline, and penicillin antibiotics from 559 aqueous solution using activated carbons: Review. Environmental Toxicology and 560 Pharmacology 50, 1-10.

561 Antonelli, M., Rossi, S., Mezzanotte, V., Nurizzo, C. 2006. Secondary Effluent 562 Disinfection: PAA Long Term Efficiency. Environmental Science \& Technology 40, 47715634775

564 Antonelli, M., Turolla, A., Mezzanotte, V., Nurizzo, C. 2013. Peracetic acid for secondary 565 effluent disinfection: A comprehensive performance assessment. Water Science \& 566 Technology 68 (12), 2638-2644.

567 Bourgin, M., Beck, B., Boehler, M., Borowska, E., Fleiner, J., Salhi, E., Teichler, R., von

568 Gunten, U., Siegrist, H., McArdell, C. S., 2018. Evaluation of a full-scale wastewater 569 treatment plant upgraded with ozonation and biological post-treatments: Abatement of 570 micropollutants, formation of transformation products and oxidation by-products. Water 571 Research 129, 486-498.

572 Brack, W., Dulio, V., Ågerstrand, M., Allan, I., Altenburger, R., Brinkmann, M., Bunke, 573 D., Burgess, R.M., Cousins, I., Escher, B.I., Hernández, F.J., Hewitt, L.M., Hilscherová, 574 K., Hollender, J., Hollert, H., Kase, R., Klauer, B., Lindim, C., López Herráez, D., Miège, 575 C., Munthe, J., O'Toole, S., Posthuma, L., Rüdel, H., Schäfer, R.B., Sengl, M., Smedes, F., 576 van de Meent, D., van den Brink, P.J., van Gils, J., van Wezel, A.P., Vethaak, A.D., 577 Vermeirssen, E., von der Ohe, P.C., Vrana, B. 2017. Towards the review of the European 578 Union Water Framework management of chemical contamination in European surface water resources. Science of the Total Environment 576, 720-737. 
580 Cai, M., Sun, P., Zhang, L., Huang, C.-H. 2017. UV/Peracetic Acid for Degradation of 581 Pharmaceuticals and Reactive Species Evaluation. Environmental Science \& Technology $58251,14217-14224$.

583 Calisto, V., Rosário Domingues, M., Erny, G.L., Esteves, V.I. 2011. Direct 584 photodegradation of carbamazepine followed by micellar electrokinetic chromatography 585 and mass spectrometry. Water Research 45, 1095-1104.

586 Caretti, C., Lubello, C. 2003. Wastewater disinfection with PAA and UV combined 587 treatment: a pilot plant study. Water Research 37, 2365-2371.

588 Cho, M., Chung, H., Choi, W., Yoon, J. 2004. Linear correlation between inactivation of 589 E. coli and $\mathrm{OH}$ radical concentration in $\mathrm{TiO} 2$ photocatalytic disinfection. Water Research 590 38, 1069-1077.

591 De Souza, J.B., Queiroz Valdez, F., Jeranoski, R.F., de Sousa Vidal, C.M., Soares 592 Cavallini, G. 2015. Water and Wastewater Disinfection with Peracetic Acid and UV 593 Radiation and Using Advanced Oxidative Process PAA/UV. International Journal of 594 Photoenergy, Article ID 860845, http://dx.doi.org/10.1155/2015/860845

595 Fatta-Kassinos, D., Manaia, C., Berendonk, T.U., Cytryn, E., Bayona, J., Chefetz, B., 596 Slobodnik, J., Kreuzinger, N., Rizzo, L., Malato, S., Lundy, L., Ledin, A. COST Action 597 ES1403: New and Emerging challenges and opportunities in wastewater REUSe 598 (NEREUS). Environmental Science Pollution Research 22, 7183-7186.

599 Ferro, G., Polo-López, M.I., Martínez-Piernas, A.B., Fernández-Ibáñez, P., Agüera A., 600 Rizzo L. 2015. Cross-Contamination of Residual Emerging Contaminants and Antibiotic 601 Resistant Bacteria in Lettuce Crops and Soil Irrigated with Wastewater Treated by 602 sunlight $/ \mathrm{H}_{2} \mathrm{O}_{2}$. Environmental Science \& Technology 49, 11096-11104. 
603 Fiorentino, A., Ferro, G., Castro, A.M., Polo-López, M.I., Fernández-Ibañez, P., Rizzo, L. 604 2015. Inactivation and regrowth of multidrug resistant bacteria in urban wastewater after 605 disinfection by solar-driven and chlorination processes. Journal of Photochemistry and 606 Photobiology B: Biology 148, 43-50.

607 Formisano, F., Fiorentino, A., Rizzo, L., Carotenuto, M., Pucci, L., Giugni, M., Lofrano, 608 G. 2016. Inactivation of Escherichia coli and Enterococci in urban wastewater by 609 sunlight/PAA and sunlight/H2O2 processes. Process Safety and Environmental Protection $610 \quad 104,178-184$.

611 Foster, H.A., Ditta, I.B., Varghese, S., Steele, A. 2011. Photocatalytic disinfection using 612 titanium dioxide: spectrum and mechanism of antimicrobial activity. Applied 613 Microbiology Biotechnology 90, 1847-1868.

614 Fu, W., Li, B., Yan, J., Y, H., Liyuan, C., Li, X. 2018. New insights into the chlorination of 615 sulfonamide: Smiles-type rearrangement, desulfation, and product toxicity. Chemical 616 Engineering Journal 331, 785-793.

617 HACH, 2014. Determination of Peracetic Acid and Hydrogen Peroxide in Water. 618 Application Note.

619 Hollender, J., Zimmermann, S.G., Koepke, S., Krauss, M., Mcardell, C.S., Ort, C., Singer, 620 H., von Gunten, U., Hansruedi, S. 2009. Elimination of Organic Micropollutants in a 621 Municipal Wastewater Treatment Plant Upgraded with a Full-Scale Post-Ozonation 622 Followed by Sand Filtration. Environmental Science \& Technology 43, 7862-7869.

623 Huang, H., Wu, Q.-Y., Tang, X., Jiang, R., Hu, H.-Y. 2016. Formation of haloacetonitriles 624 and haloacetamides and their precursors during chlorination of secondary effluents. 625 Chemosphere 144, 297-303. 
626 ISO 16075 (2015). Guidelines for Treated Wastewater Use for Irrigation Projects.

627 International Organization for Standardization, Geneva, Switzerland.

628 JRC (Joint Research Centre), 2015. Development of the first Watch List under the 629 Environmental Quality Standards Directive: Directive 2008/105/EC, as amended by 630 Directive 2013/39/EU, in the field of water policy. Raquel N. Carvalho, Lidia Ceriani, 631 Alessio Ippolito and Teresa Lettieri. Report EUR 27142 EN.

632 Karaolia, P., Michael-Kordatou, I., Hapeshi, E., Alexander, J., Schwartz, T., Fatta633 Kassinos, D. 2017. Investigation of the potential of a Membrane BioReactor followed by 634 solar Fenton oxidation to remove antibiotic-related microcontaminants. Chemical 635 Engineering Journal 310, 491-502.

636 Keun-Young, P., Su-Young C., Seung-Hoon L., Ji-Hyang K., Ji-Hyeon S. 2016. 637 Comparison of formation of disinfection by-products by chlorination and ozonation of 638 wastewater effluents and their toxicity to Daphnia magna. Environmental Pollution 215, $639 \quad 314-321$.

640 Klamerth, N., Rizzo, L., Malato, S., Maldonado, M.I., Agüera, A., Fernández-Alba, A.R. 641 2010. Degradation of fifteen emerging contaminants at $\mu \mathrm{g}$ L-1 initial concentrations by 642 mild solar photo-Fenton in MWTP effluents. Water Research 44, 545-554.

643 Koivunen, J., Heinonen-Tanski, H. 2005. Inactivation of enteric microorganisms with 644 chemical disinfectants, UV irradiation and combined chemical/UV treatments. Water 645 Research 39, 1519-1526.

646 Kowalski, W. 2009. Ultraviolet Germicidal Irradiation Handbook, DOI 10.1007/978-3647 642-01999-9_2, Springer-Verlag Berlin Heidelberg. 
648 Krzeminski, P., Tomei, M.C., Karaolia, P., Langenhoff, A., Almeida, C.M.A., Felis, E., 649 Gritten, F., Andersen, H.R., Fernandes T., Manaia, C.M., Rizzo, L., Fatta-Kassinos, D. 650 2019. Performance of secondary wastewater treatment methods for the removal of 651 contaminants of emerging concern implicated in crop uptake and antibiotic resistance 652 spread: A review. Science of the Total Environment 648, 1052-1081.

653 Lian, J., Qiang, Z., Li, M., Bolton, J.R., Qu, J. 2015. UV photolysis kinetics of 654 sulfonamides in aqueous solution based on optimized fluence quantification. Water 655 Research 75, 43-50.

656 Lubello, C., Caretti, C., Gori, R., 2002. Comparison between PAA/UV and H2O2/UV 657 disinfection for wastewater reuse. Water Science and Technology.: Water Supply 2(1), $658 \quad 205-212$.

659 Malato, S., Fernandez-Ibanez, P., Maldonado, M.I., Blanco, J., Gernjak, W., 2009. 660 Decontamination and disinfection of water by solar photocatalysis: recent overview and 661 trends. Catalysis Today 147, 1-59.

662 Martin, N., Gehr, R., 2007. Reduction of Photoreactivation with the Combined 663 UV/Peracetic Acid Process or by Delayed Exposure to Visible Light. Water Environment 664 Research 79, 991-999.

665 McGuigan, K.G., Conroy, R.M., Mosler, H.-J., du Preez, M., Ubomba-Jaswa, E., 666 Fernandez-Ibanez, P. 2012. Solar water disinfection (SODIS): a review from bench-top to 667 roof-top. Journal of Hazardous Materials 235-236, 29-46.

668 Petrie, B., Barden, R., Kasprzyk-Hordern B. 2015. A review on emerging contaminants in 669 wastewaters and the environment: Current knowledge, understudied areas and 670 recommendations for future monitoring. Water Research 72, 3-27. 
671 Polo-López, M.I., Fernández-Ibáñez, P., García-Fernández, I., Oller, I., Salgado-Tránsito,

672 I., Sichel, C. 2010. Resistance of Fusarium sp spores to solar $\mathrm{TiO}_{2}$ photocatalysis:

673 influence of spore type and water (scaling-up results). Journal of Chemical Technology

674 and Biotechnology 85, 1038-1048.

675 Rizzo, L., Della Sala, A., Fiorentino, A., Li Puma, G. 2014. Disinfection of urban 676 wastewater by solar driven and UV lamp - TiO2 photocatalysis: effect on a multi drug 677 resistant Escherichia coli strain, Water Research 53, 145-152.

678 Rizzo, L., Fiorentino, A., Anselmo, A. 2012. Effect of solar radiation on multidrug 679 resistant E. coli strains and antibiotic mixture photodegradation in wastewater polluted 680 stream. Science of the Total Environment 427-428, 263-268.

681 Rizzo, L., Fiorentino, A., Grassi, M, Attanasio, D., Guida M. 2015. Advanced treatment of 682 urban wastewater by sand filtration and graphene adsorption for wastewater reuse: Effect 683 on a mixture of pharmaceuticals and toxicity. Journal of Environmental Chemical 684 Engineering 3, 122-128.

685 Rizzo, L., Kraetke, R., Linders, J., Scott, M., Vighi, M., de Voogt, P. 2018. Proposed EU 686 minimum quality requirements for water reuse in agricultural irrigation and aquifer 687 recharge: SCHEER scientific advice. Current Opinion in Environmental Science \& Health $688 \quad 2,7-11$.

689 Rizzo, L., Manaia, C.M., Merlin, C., Schwartz, T., Dagot, C., Ploy, M.C., Michael, I., 690 Fatta-Kassinos, D., 2013. Urban wastewater treatment plants as hotspots for antibiotic 691 resistant bacteria and genes spread into the environment: a review. Science of the Total 692 Environment 447, 345-360. 
693 Sacco, O., Vaiano, V., Rizzo, L., Sannino, D. 2018. Photocatalytic activity of a visible 694 light active structured photocatalyst developed for municipal wastewater treatment. Journal 695 of Cleaner Production 175, 38-49.

696 Trovó, A.G., Nogueira, R.F.P., Agüera, A., Sirtori, C., Fernández-Alba, A.R. 2009. 697 Photodegradation of sulfamethoxazole in various aqueous media: Persistence, toxicity and 698 photoproducts assessment. Chemosphere 77, 1292-1298.

699 USEPA. 2012. Guidelines for water reuse. (EPA/600/R-12/618) United States 700 Environmental Protection Agency, Washington, DC, USA.

701 Yuan, Q., Guo, M., Yang, J. 2015. Fate of antibiotic resistant bacteria and genes during 702 wastewater chlorination: implication for antibiotic resistance control. PloS One 10 (3), $703 \mathrm{e} 0119403$.

704 Zhang, C., Brown, P.J.B., Hu, Z. 2018. Thermodynamic properties of an emerging 705 chemical disinfectant, peracetic acid. Science of the Total Environment 621, 948-959.

706 Zhang, N., Liu, G, Liu, H., Wang, Y., He, Z., Wang, G. 2011. Diclofenac 707 photodegradation under simulated sunlight: Effect of different forms of nitrogen and 708 Kinetics. Journal of Hazardous Materials 192, 411-418. 
709 Figure captions

710 Figure 1. Inactivation of AR E. coli: control tests in dark with PAA and sunlight as

711 standalone processes. QUv values are given between brackets.

712 Figure 2. Inactivation of AR E. coli by sunlight/PAA in CPC: effect of initial PAA 713 concentration.

714 Figure 3. Degradation of CECs: control tests with PAA and sunlight as standalone 715 processes.

716 Figure 4. Effect of sunlight/PAA process on CECs in GW: CBZ (a), DCF (b) and SMX (c).

717 Figure 5. Effect of sunlight/PAA process on CECs in WW: CBZ (a), DCF (b) and SMX 718 (c)

719 Figure 6. Inactivation of AR E. coli by UV-C/PAA process.

720 Figure 7. Effect of UV-C/PAA process on CBZ in GW (a) and WW (b).

721 Figure 8. Effect of UV-C/PAA process on DCF in GW (a) and WW (b). 
Table 1: physical-chemical characteristics of GW and WW samples.

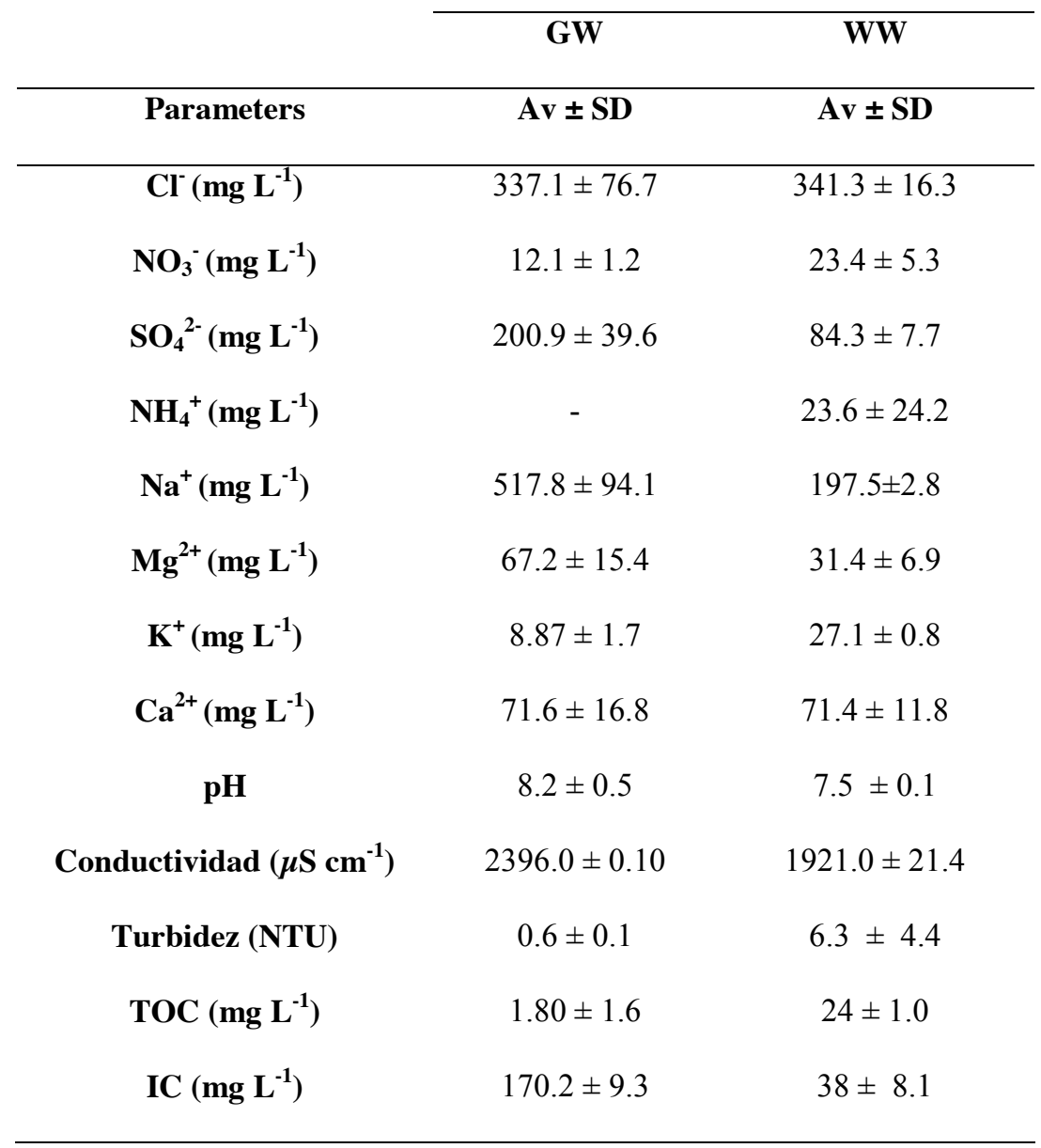




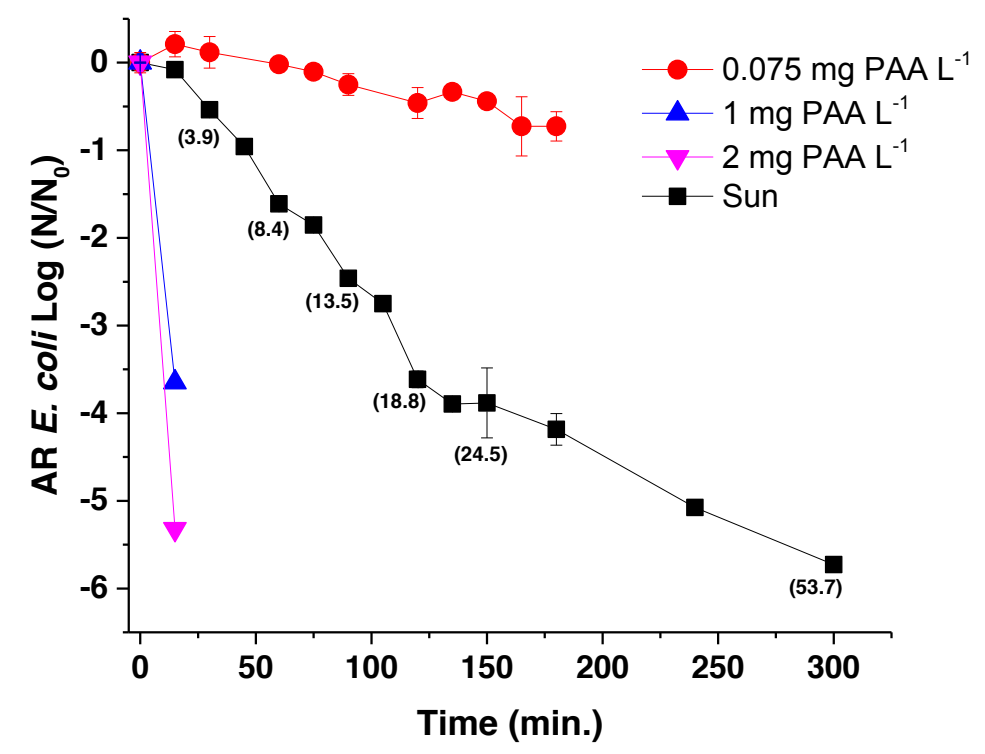

Figure 1 


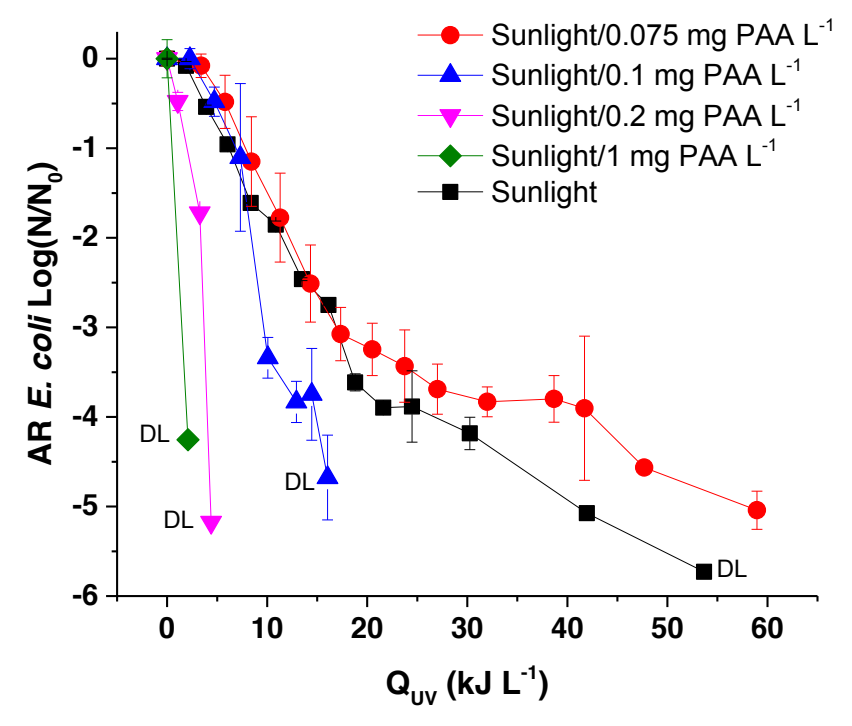

a)

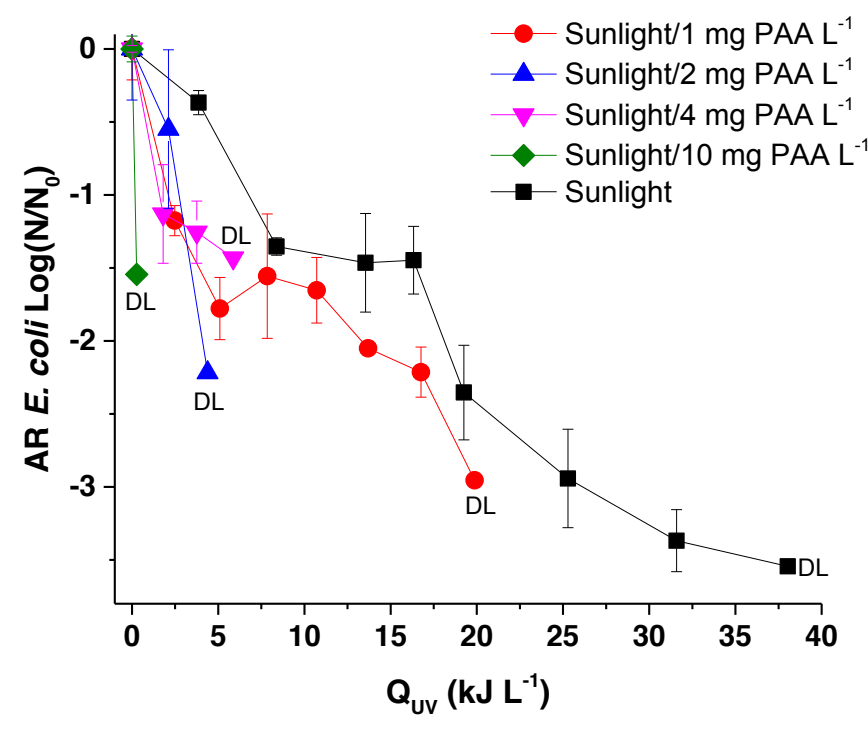

b)

Figure 2 


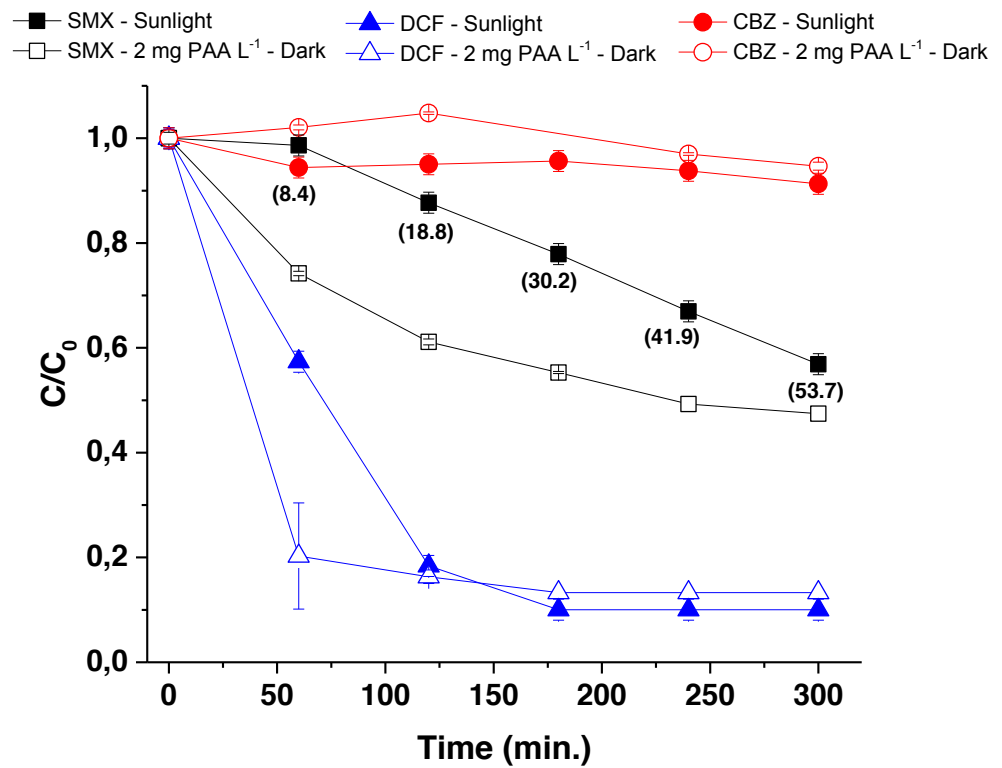

Figure 3 


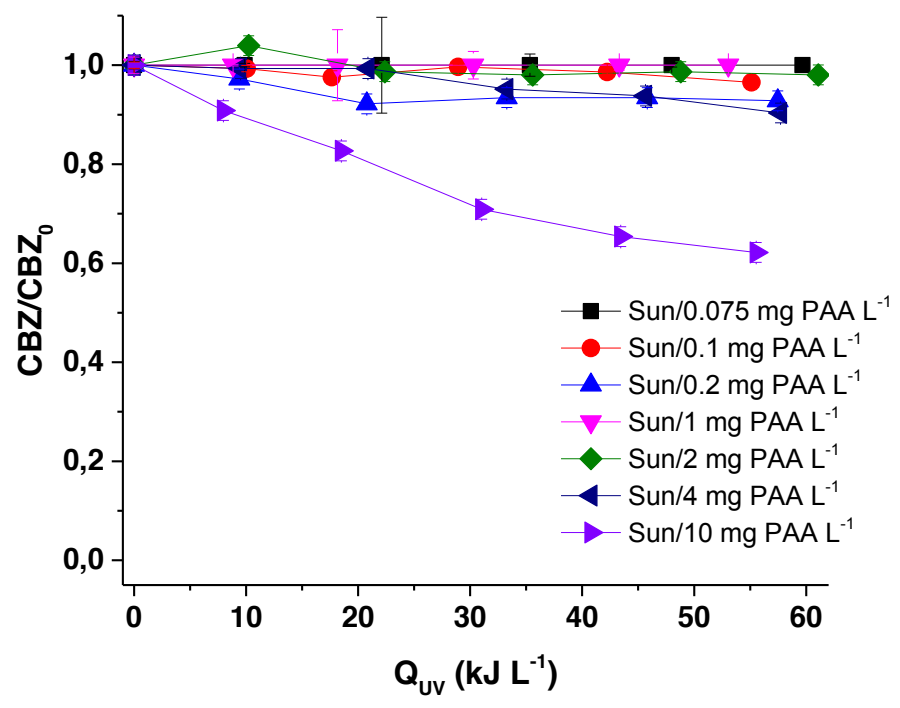

a)

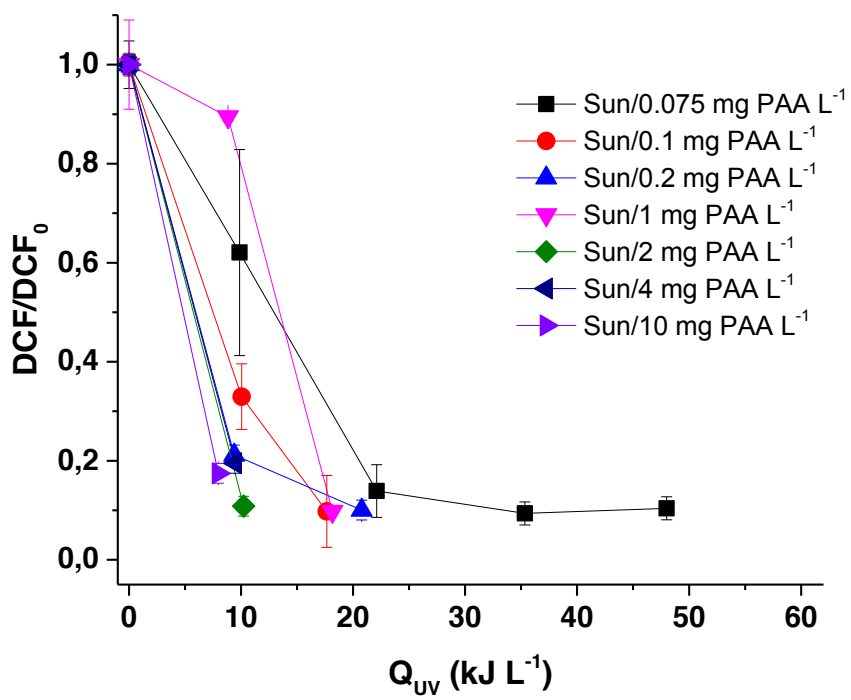

b)

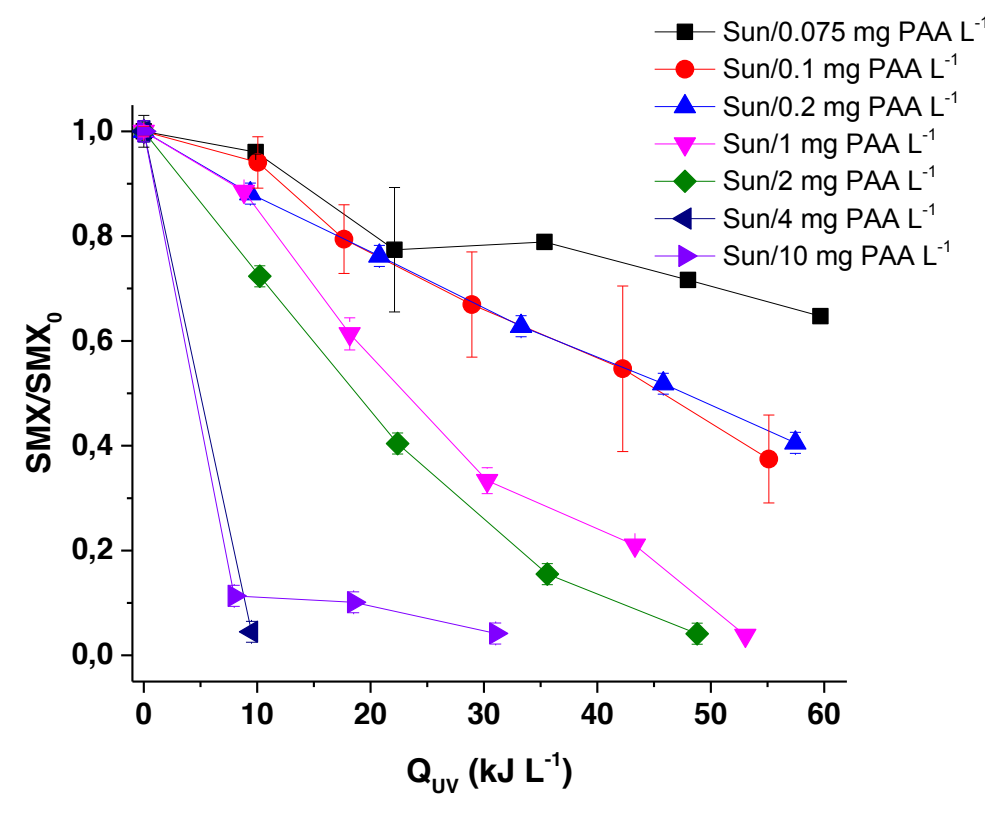

c)

Figure 4 


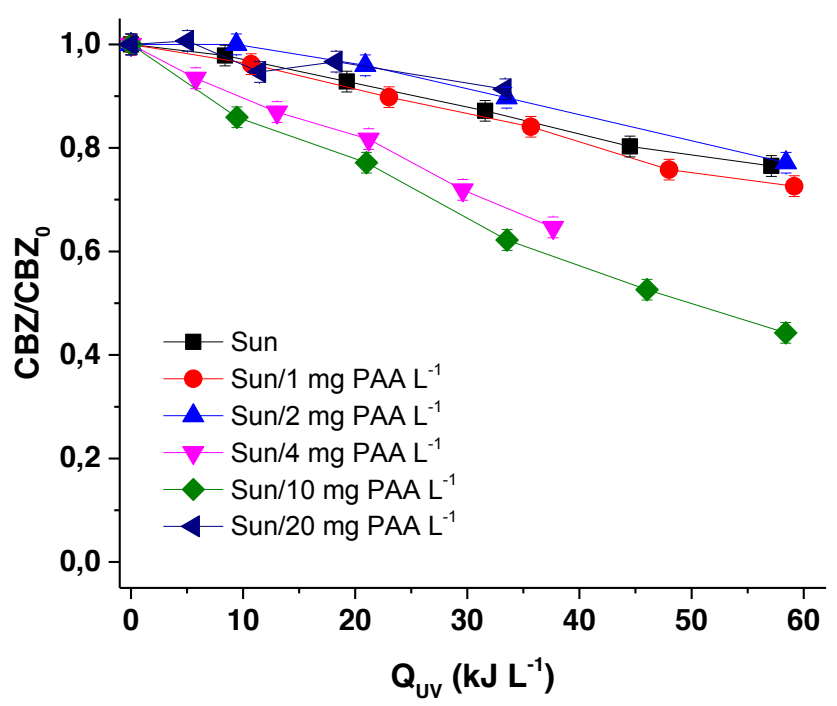

a)

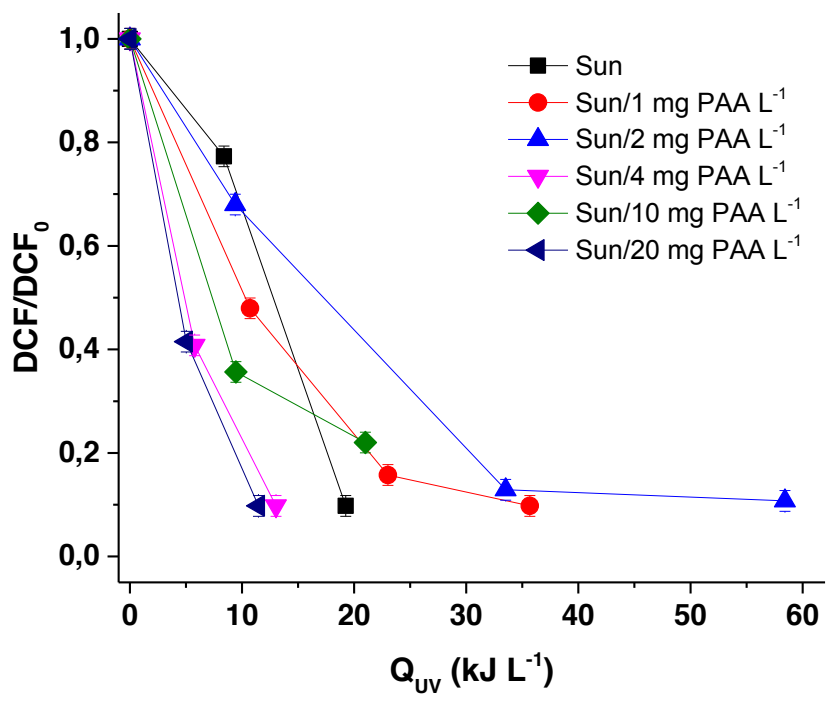

b)

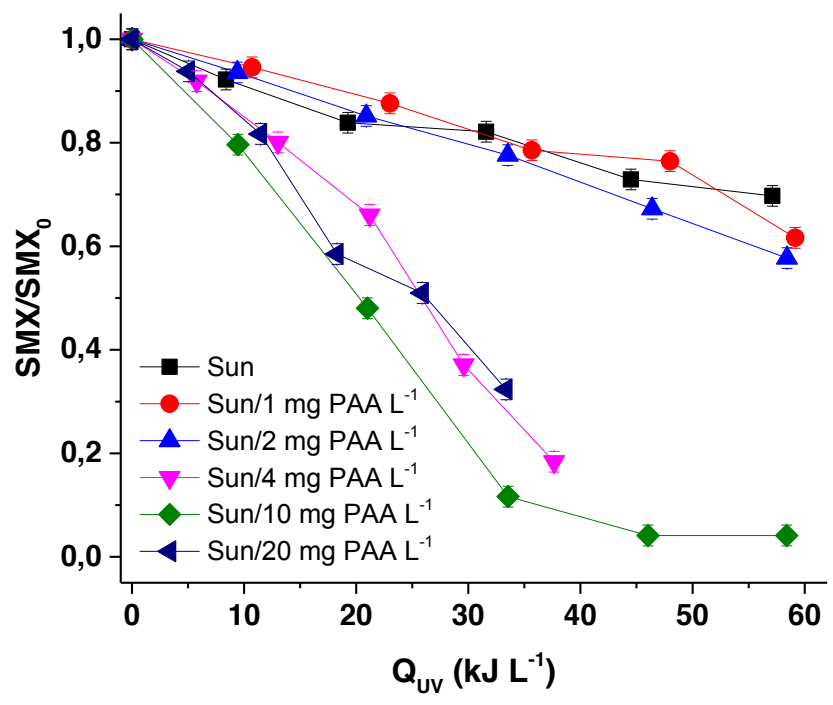

c)

Figure 5 


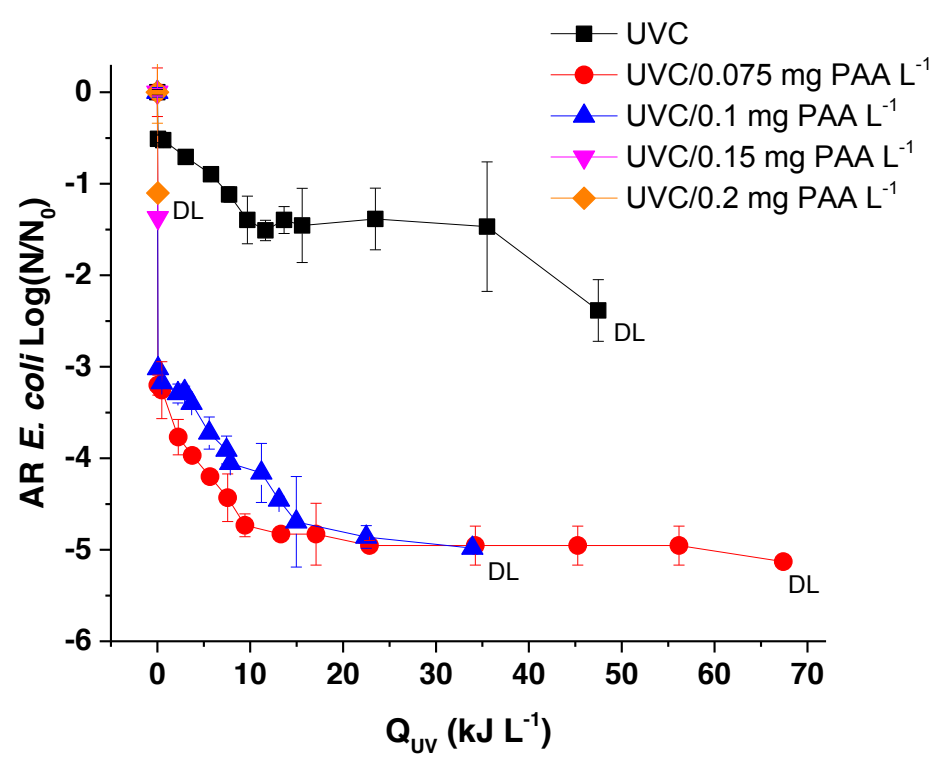

Figure 6 


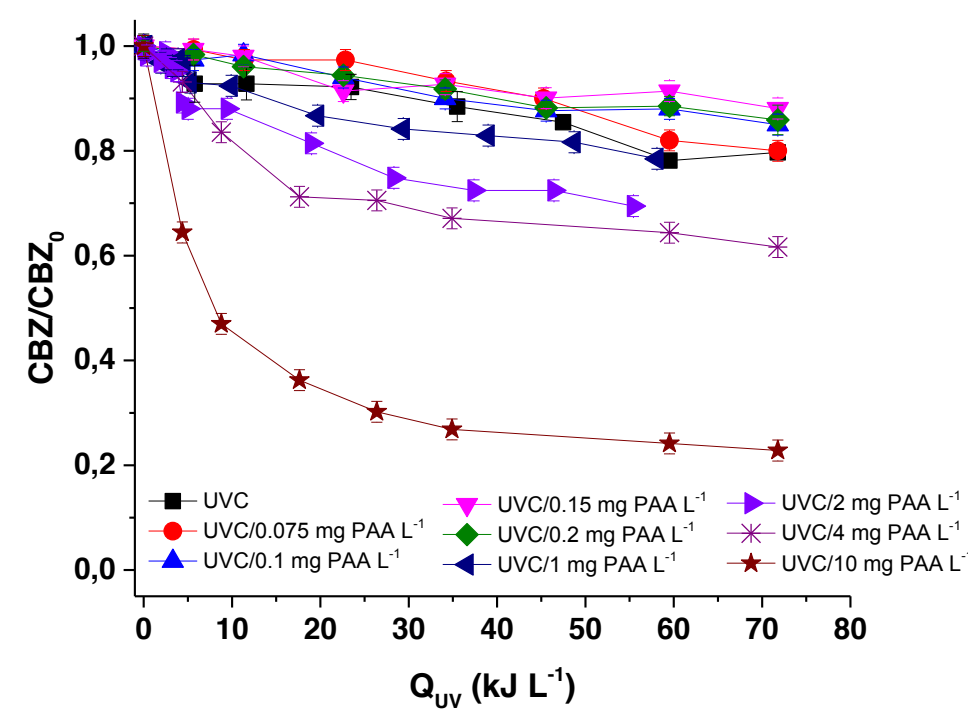

a)

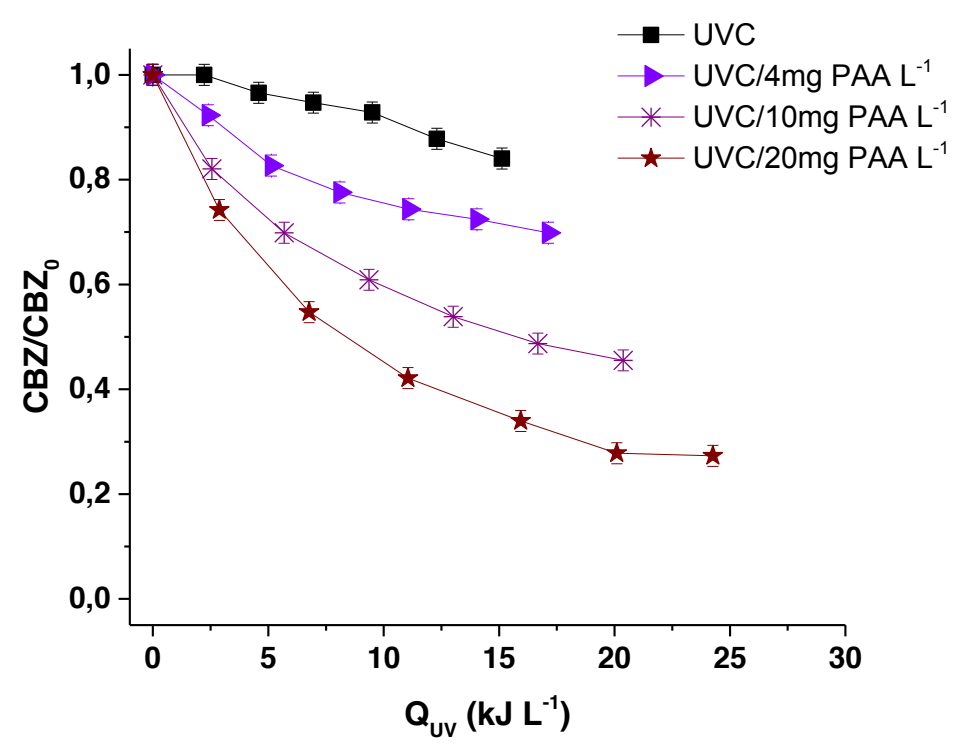

b)

Figure 7 


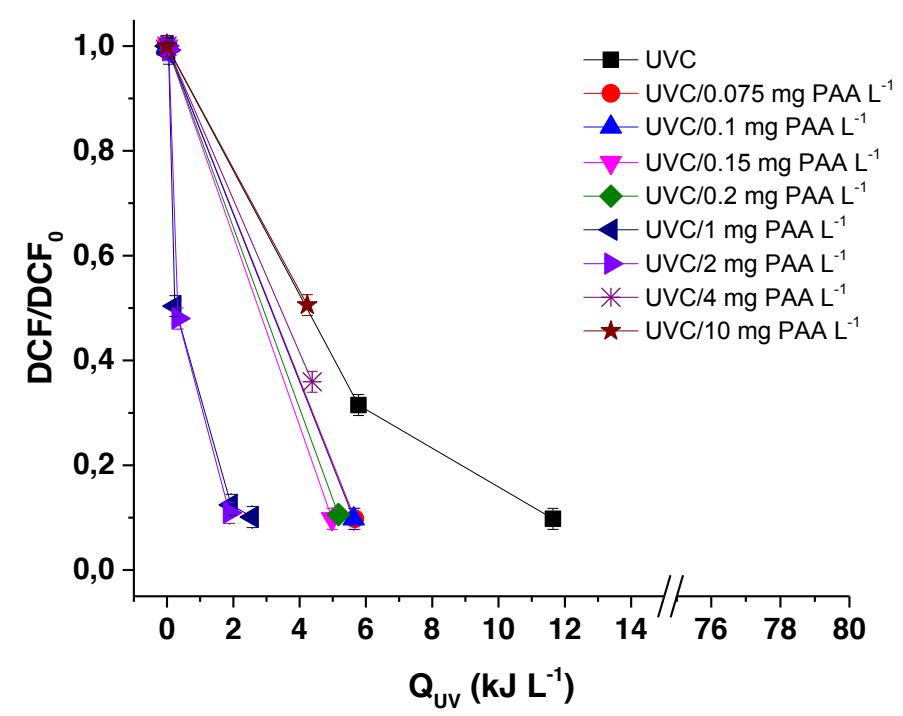

a)

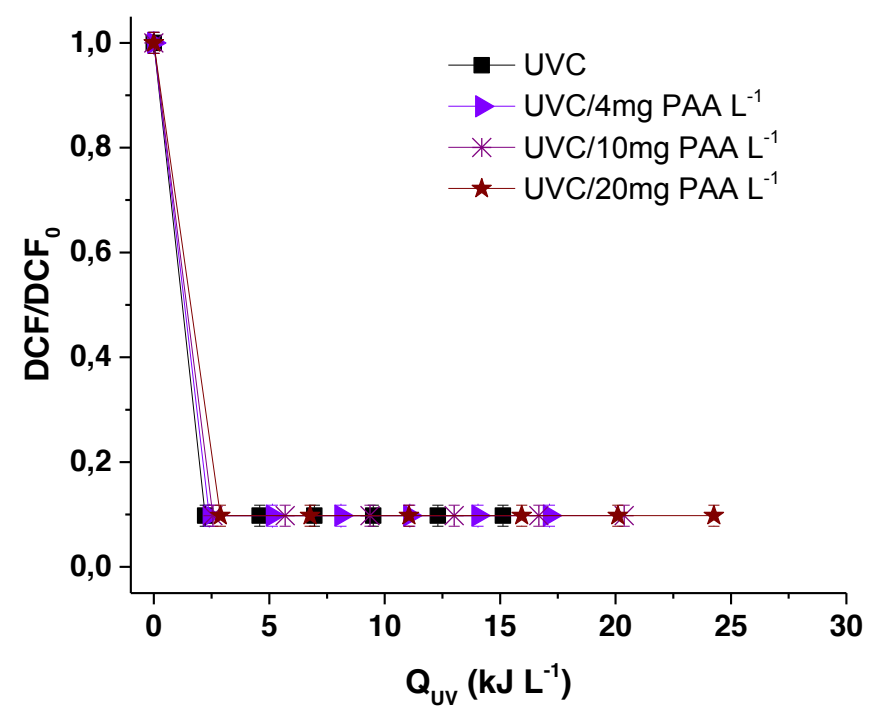

b)

Figure 8 
